\title{
Purification, Purity, and Freezing Points of $n$-Decane, 4 Alkylcyclopentanes, 9 Alkylcyclohexanes, 2 Monoolefins, 1, 2-Butadiene, and 2-Butyne of the API- Standard and API-NBS Series ${ }^{1 *}$
}

\author{
By Anton J. Streiff ${ }^{2}$ Evelyn T. Murphy, ${ }^{2}$ Janice C. Zimmerman ${ }^{2}{ }^{2}$ Laurel F. Soule, ${ }^{2}$ \\ Vincent A. Sedlak, ${ }^{2}$ Charles B. Willingham, and Frederick D. Rossini
}

This report describes the purification and determination of freezing points and purity of 18 hydrocarbons of the API-Standard and API-NBS series, including one paraffin, four alkylcyclopentanes, nine alkylcyclohexanes, two monoolefins, one diolefin, and one acetylene.

\section{Introduction}

Previous reports described the purification and determination of freezing points and purity of 66 hydrocarbon compounds of the API-Standard and API-NBS series, which were produced as part of the cooperative program on standard samples of hydrocarbons of the National Bureau of Standards and the American Petroleum Institute [1, 2, 3]. ${ }^{3}$ This report describes the purification and determination of freezing points and purity of an additional 18 hydrocarbon compounds under this cooperative program, including $n$-decane, 4 alkylcyclopentanes, 9 alkylcyclohexanes, 2 monoolefins, 1,2-butadiene and 2-butyne.

The final lots of the material labeled APIStandard are sealed "in vacuum" in glass ampoules and made available as NBS standard samples of hydrocarbons, by the American Petroleum Institute and the National Bureau of Standards. The material labeled API-NBS is made available in appropriate small lots, through the American Petroleum Institute Research Project 44 at the National Bureau of Standards, on loan to qualified investigators for the measurement of needed properties.

1 This investigation was performed at the National Bureau of Standards as part of the work of the American Petroleum Institute Research Project 6 on the Analysis, Purification, and Properties of Hydrocarbons.

*Presented before the Division of Petroleum Chemistry of the American Chemical Society at the meeting in New York, September 1947.

${ }_{2}$ Research Associate on the American Petroleum Institute Research Project 6 at the National Bureau of Standards.

3 Figures in brackets indicate the literature references at the end of this paper.

\section{Materials}

The starting materials were supplied as follows:

By the API Research Project 45 on the "Synthesis and Properties of Hydrocarbons of LowMolecular Weight" at the Ohio State University, Columbus, Ohio, under the supervision of C. E. Boord :

Isobutylcyclopentane. cis-1,3-Dimethylcyclo-

hexane.

trans-1,3-Dimethylcyclo-

hexane.

n-Propylcyclohexane.

Isopropylcyclohexane.

\author{
1,1,3-Trimethyleyclo- \\ hexane. \\ $n$-Butyleyclohexane. \\ Isobutylcyclohexane. \\ sec-Butylcyclohexane. \\ tert-Butylcyclohexane. \\ 2-Butyne.
}

By the Hydrocarbon Laboratory at the Pennsylvania State College, State College, Pa., under the supervision of F. C. Whitmore:

\section{1-Methyl-1-ethylcyclopentane. cis-1-Methyl-2-ethylcyclopentane. \\ 3,3-Dimethyl-1-butene.}

By the Standard Oil Development Co., Esso Laboratories, Elizabeth, N. J., and Baton Rouge, La., through W. J. Sweeney:

\section{1,2-Butadiene.}

By the Tide Water Associated Oil Co., Associated, Calif., through H. Y. Hyde:

$$
\text { Cyclopentane (B) }{ }^{4}
$$

By the API Research Project 6 at the National Bureau of Standards, through F. D. Rossini :

$$
\begin{aligned}
& n \text {-Decane. } \\
& \text { 1-Octene. }
\end{aligned}
$$

+ See footnote "a" of table 2 
TABLE 1.-Information on the purification of 18 API-Standard and API-NBS hydrocarbons

\begin{tabular}{|c|c|c|c|c|c|c|c|c|c|c|c|c|c|}
\hline \multirow{4}{*}{ Compound ${ }^{\circ}$} & \multirow{4}{*}{$\begin{array}{l}\text { Siarting } \\
\text { material } \\
\text { provided } \\
\text { by }\end{array}$} & \multirow{3}{*}{\multicolumn{2}{|c|}{$\begin{array}{l}\text { Hydrocarbon } \\
\text { charged } \\
\text { for } \\
\text { distillation }\end{array}$}} & \multicolumn{8}{|c|}{ Distillation ${ }^{f}$} & \multirow{2}{*}{\multicolumn{2}{|c|}{$\begin{array}{c}\text { Volume of } \\
\text { selected sample }\end{array}$}} \\
\hline & & & & \multirow{3}{*}{ Kind $^{c}$} & \multirow{3}{*}{$\begin{array}{l}\text { Azeo- } \\
\text { trope- } \\
\text { forming } \\
\text { sub- } \\
\text { stance }\end{array}$} & \multirow{3}{*}{$\begin{array}{l}\text { Amount of } \\
\text { hydrocarbon } \\
\text { in the } \\
\text { azeotropic } \\
\text { distillate }^{\mathrm{e}}\end{array}$} & \multirow{3}{*}{$\begin{array}{l}\text { Distilling } \\
\text { column } \\
\text { number }\end{array}$} & \multirow{3}{*}{$\begin{array}{l}\text { Number } \\
\text { of } \\
\text { theor- } \\
\text { etical } \\
\text { plates } \\
\text { (approx.) }\end{array}$} & \multirow{3}{*}{$\begin{array}{l}\text { Reflux } \\
\text { ratio } \\
\text { (approx.) }\end{array}$} & \multirow{3}{*}{$\begin{array}{l}\text { Rate of } \\
\text { collection } \\
\text { of } \\
\text { distillate }\end{array}$} & \multirow{3}{*}{$\begin{array}{c}\text { Results } \\
\text { plotted } \\
\text { in } \\
\text { figure }\end{array}$} & & \\
\hline & & & & & & & & & & & & API- & API- \\
\hline & & Volume & Purity & & & & & & & & & Standard & NBS \\
\hline & laboratory ${ }^{b}$ & liters & $\begin{array}{c}\text { mole } \\
\text { percent }\end{array}$ & & & $\begin{array}{l}\text { percentage } \\
\text { by volume }\end{array}$ & & & & $\mathrm{ml} /$ hour & & $\mathrm{ml}$ & $\mathrm{ml}$ \\
\hline \multicolumn{14}{|l|}{ Paraffins } \\
\hline$n$-Decane & APIRP $6^{9}$ & $\begin{array}{l}\mathrm{h}_{5} .80 \\
\mathrm{i}^{5} .80\end{array}$ & $\begin{array}{l}98.55 \pm 0.06 \\
99.84 \pm 0.02\end{array}$ & $\begin{array}{l}\text { Reg. } \\
\text { Reg. }\end{array}$ & & & $\begin{array}{r}14 \\
7\end{array}$ & $\begin{array}{l}125 \\
130\end{array}$ & $\begin{array}{l}125 / 1 \\
145 / 1\end{array}$ & $\begin{array}{r}12.5 \\
8.5\end{array}$ & $\begin{array}{l}1 \\
2\end{array}$ & 1400 & 415 \\
\hline \multicolumn{14}{|l|}{ Alkyicyclopentanes } \\
\hline Cyclopentane (B) & Tide Water Assoc & 2.45 & $99.84 \pm 0.02$ & Reg. & & & 2 & 100 & $150 / 1$ & 2.0 & 3 & 1020 & 300 \\
\hline |-Methyl-1-ethylcyclopentane & Penn State & 2.10 & & Azeo. & Ethanol & 33 & 4 & 200 & $180 / 1$ & 4.0 & 4 & 1240 & 370 \\
\hline cis-1-Methyl-2-ethylcyclopentane & Penn State & 1.73 & $94.0 \pm 0.5$ & Azeo. & Isopropanol & 14 & 4 & 200 & $180 / 1$ & 4.0 & 5 & 716 & 158 \\
\hline $\begin{array}{l}\text { Isobutylcyclopentane } \\
\text { Alkylcyclohexanes }\end{array}$ & APIRP 45 & $\begin{array}{l}3.19 \\
2.25\end{array}$ & $9982 \pm 0.08$ & $\begin{array}{l}\text { Reg. } \\
\text { Azeo. }\end{array}$ & Cell. & 59 & $\begin{array}{l}13 \\
10\end{array}$ & $\begin{array}{l}130 \\
135\end{array}$ & $\begin{array}{l}155 / 1 \\
165 / 1\end{array}$ & $\begin{array}{l}8.0 \\
4.5\end{array}$ & $\begin{array}{l}6 \\
7\end{array}$ & 1060 & 290 \\
\hline cis-1,3-Dimethylcyclohexane & APIRP 45 & $\begin{array}{l}1590 \\
m_{5.98} \\
2.60\end{array}$ & $99.89 \pm 0.05$ & $\begin{array}{l}\text { Reg. } \\
\text { Reg. } \\
\text { Azeo. }\end{array}$ & Me. Cell. & 66 & $\begin{array}{c}15 \\
7 \\
15 A\end{array}$ & $\begin{array}{l}125 \\
130 \\
200\end{array}$ & $\begin{array}{l}125 / 1 \\
145 / 1 \\
160 / 1\end{array}$ & $\begin{array}{r}12.5 \\
8.5 \\
4.5\end{array}$ & $\begin{array}{c}8 \\
9 \\
10\end{array}$ & 1200 & 360 \\
\hline trans-1,3-Dimethylc yclohexane ${ }^{k}$ & APIRP 45 & $\begin{array}{r}15.90 \\
m 3.00\end{array}$ & & $\begin{array}{l}\text { Reg. } \\
\text { Azeo. }\end{array}$ & Ethand & 35 & $\begin{array}{l}15 \\
9\end{array}$ & $\begin{array}{l}125 \\
135\end{array}$ & $\begin{array}{l}125 / 1 \\
165 / 1\end{array}$ & $\begin{array}{r}12.5 \\
4.5\end{array}$ & $\begin{array}{l}8 \\
11\end{array}$ & 1100 & 360 \\
\hline n-Propylcyclohexane & APIRP 45 & $\begin{array}{r}1.48 \\
1.05 \\
0 \\
0 \\
2.25\end{array}$ & $99.48 \pm 0.08$ & $\begin{array}{l}\text { Reg. } \\
\text { Azeo. } \\
\text { Azeo. }\end{array}$ & $\begin{array}{l}\text { Cell. } \\
\text { Cell. }\end{array}$ & $\begin{array}{l}40 \\
40\end{array}$ & $\begin{array}{l}8 \\
9 \\
9\end{array}$ & $\begin{array}{l}130 \\
135 \\
135\end{array}$ & $\begin{array}{l}145 / 1 \\
165 / 1 \\
165 / 1\end{array}$ & $\begin{array}{l}8.5 \\
4.5 \\
4.5\end{array}$ & $\begin{array}{l}12 \\
13 \\
14\end{array}$ & $\left.\begin{array}{l}365 \\
895\end{array}\right\}^{p}$ & 360 \\
\hline Isopropylcyclohexane & APIRP 45 & $\begin{array}{l}390 \\
179\end{array}$ & $98.8 \pm 0.1$ & $\begin{array}{l}\text { Reg. } \\
\text { Azeo. }\end{array}$ & Cell. & 43 & $\begin{array}{c}8 \\
10\end{array}$ & $\begin{array}{l}130 \\
135\end{array}$ & $\begin{array}{l}155 / 1 \\
165 / 1\end{array}$ & $\begin{array}{l}8.0 \\
4.5\end{array}$ & $\begin{array}{l}15 \\
16\end{array}$ & 875 & 147 \\
\hline 1,1,3-Trimethylcyclohexane & APIRP45 & $\begin{array}{r}2.72 \\
1.80\end{array}$ & $99.64 \pm 008$ & $\begin{array}{l}\text { Reg. } \\
\text { Azeo. }\end{array}$ & Me. Cell. & 63 & $\begin{array}{r}7 \\
10\end{array}$ & $\begin{array}{l}130 \\
135\end{array}$ & $\begin{array}{l}155 / 1 \\
\mid 65 / 1\end{array}$ & $\begin{array}{l}8.0 \\
4.5\end{array}$ & $\begin{array}{l}17 \\
18\end{array}$ & 905 & 199 \\
\hline n-Butylcyclohexane & APIRP45 & $\begin{array}{l}2.50 \\
171\end{array}$ & $99.87 \pm 0.08$ & $\begin{array}{l}\text { Reg. } \\
\text { Azeo. }\end{array}$ & Butyl Cell. & 52 & $\begin{array}{l}13 \\
10\end{array}$ & $\begin{array}{l}130 \\
135\end{array}$ & $\begin{array}{l}155 / 1 \\
165 / 1\end{array}$ & $\begin{array}{l}8.0 \\
4.5\end{array}$ & $\begin{array}{l}19 \\
20\end{array}$ & 870 & 215 \\
\hline Isobutylcyclohexane & APIRP 45 & $\begin{array}{l}1.91 \\
1.5 .3\end{array}$ & $99.75 \pm 0.09$ & $\begin{array}{l}\text { Reg. } \\
\text { Azeo. }\end{array}$ & Butyl Cell. & 63 & $\begin{array}{c}2 \\
\| A\end{array}$ & $\begin{array}{r}100 \\
200\end{array}$ & $\begin{array}{l}150 / 1 \\
160 / 1\end{array}$ & $\begin{array}{l}2.0 \\
4.5\end{array}$ & $\begin{array}{l}21 \\
22\end{array}$ & 930 & 185 \\
\hline sec-Butylcyclohexane & APIRP 45 & $\begin{array}{l}2.59 \\
2.13\end{array}$ & & $\begin{array}{l}\text { Reg. } \\
\text { Azeo. }\end{array}$ & Butyl Cell. & 54 & $\begin{array}{l}12 \\
11 \mathrm{~A}\end{array}$ & $\begin{array}{l}135 \\
200\end{array}$ & $\begin{array}{l}165 / 1 \\
160 / 1\end{array}$ & $\begin{array}{l}4.5 \\
4.5\end{array}$ & $\begin{array}{l}23 \\
24\end{array}$ & 975 & 210 \\
\hline tert-Butylcyclohexone & APIRP 45 & $\begin{array}{l}2.53 \\
1.68\end{array}$ & $99.94 \pm 0.03$ & $\begin{array}{l}\text { Reg. } \\
\text { Azeo }\end{array}$ & Cell. & 26 & $\begin{array}{c}12 \\
8\end{array}$ & $\begin{array}{l}135 \\
130\end{array}$ & $\begin{array}{l}165 / 1 \\
145 / 1\end{array}$ & $\begin{array}{l}4.5 \\
8.5\end{array}$ & $\begin{array}{l}25 \\
26\end{array}$ & 1135 & 285 \\
\hline \multicolumn{14}{|l|}{ Olefins } \\
\hline 3,3-Dimethyl-1-butene & Penn State & 3.80 & $98.86 \pm 0.15$ & Reg. & & & 9 & 135 & $165 / 1$ & 4.5 & 27 & 1300 & 385 \\
\hline 1-Octene & APIRP $^{9}$ & $\begin{array}{l}{ }^{a} 6.00 \\
{ }^{1} 6.15\end{array}$ & $99.70 \pm 0.13$ & $\begin{array}{l}\text { Reg. } \\
\text { Reg. }\end{array}$ & & & $\begin{array}{l}13 \\
13\end{array}$ & $\begin{array}{l}130 \\
130\end{array}$ & $\begin{array}{l}155 / 1 \\
155 / 1\end{array}$ & $\begin{array}{l}8.0 \\
8.0\end{array}$ & $\begin{array}{l}28 \\
29\end{array}$ & 2000 & 600 \\
\hline \multicolumn{14}{|l|}{ Diolefins } \\
\hline 1,2-Butadiene & Std Oil Dev. & $\begin{array}{l}1.40 \\
1.00\end{array}$ & & $\begin{array}{l}\text { Reg } \\
\text { Reg. }\end{array}$ & & & $\begin{array}{l}1 \\
1\end{array}$ & $\begin{array}{l}150 \\
150\end{array}$ & $\begin{array}{l}150 / 1 \\
150 / 1\end{array}$ & $\begin{array}{l}2.0 \\
2.0\end{array}$ & $\begin{array}{l}30 \\
31\end{array}$ & 600 & 100 \\
\hline \multicolumn{14}{|l|}{ Acetylenes } \\
\hline 2-Butyne & APIRP 45 & 2.68 & & Reg & & & 1 & 150 & $150 / 1$ & 2.0 & 32 & 1125 & 265 \\
\hline
\end{tabular}

See footnotes on page $32: 3$. 
Table 1 summarizes the amounts of the starting materials and gives some additional information as to the source and purity.

\section{Purification}

The procedure followed in the process of purification and determination of purity was the same as that described in the previous reports $[2,3]$.

In addition to the name of the laboratory supplying the starting materials, table 1 and its footnotes give complete information for each distillation for each of the compounds.

Details of the distillation apparatus and operations are described in reference [5].

\section{Footnotes for Table 1, Page 322.}

a See footnote "a" of table 2 .

b The abbreviations represent the following laboratories:

A PIR P45; American Petroleum Institute Research Project 45 at the Ohio State University, Columbus, Ohio.

Penn State; Hydrocarbon Laboratory at the Pennsylvania State College, State College, Pa.

Std. Oil Dev.; Standard Oil Development Co. Esso Laboratories, Elizabeth, N. J. and Baton Rouge, La.

Tide Water Assoc.; Tide Water Associated Oil Co., Associated, Calif.

A PIRP6; American Petroleum Institute Research Project 6 at the National Bureau of Standards, Washington 25, D. C.

c The abbreviations are: Azeo., azeotropic; Reg., regular.

d The abbreviations are: Cell., Cellosolve (ethylene glycol monoethyl ether); me. Cell., methyl Cellosolve (ethylene glycol monomethyl ether); Butyl Cell., butyl Cellosolve (ethylene glycol monobutyl ether).

e Approximate value obtained from the actual volume of hydrocarbon recovered by extracting the azeotrope-forming substance with water in separatory funnels.

$t$ See reference [5] for further details.
Figures 1 to 32 , inclusive, show graphically the results of the distillations listed in table 1 . These figures give, as a function of volume of hydrocarbon distillate, the refractive index $\left(n_{D}\right.$ at $25^{\circ} \mathrm{C}$, to \pm 0.0001 ), the boiling point of the distillate (at the controlled pressure of $724.5 \mathrm{~mm} \mathrm{Hg}$, to $\pm 0.01^{\circ} \mathrm{C}$ ), the freezing point of selected fractions of hydrocarbon distillate (in air at $1 \mathrm{~atm}$ usually with a precision near $\pm 0.003^{\circ} \mathrm{C}$ ), and the purity of the hydrocarbon distillate. The letters $W, X$, $Y, Z$ indicate the disposition of the material, as follow: $W$, returned to the laboratory supplying the material; $X$, blended for redistillation; $Y$, used for the API-Standard material; $Z$, used for the API-NBS material.

g Obtained by purchase of commercially available material from the Connecticut Hard Rubber Co., New Haven, Conn.

h One of two similar charges.

i This charge consisted of material, having substantially the same composition, from each of the two previous distillations (see footnote " $h$ ").

j See footnote "f" of table 2.

k See footnote "g" of table 2.

1 One of three charges of similar material, two of which were 5.90 liters each, and the third of which was 2.50 liters. Both cis and trans-1,3-dimethyicyclohexane were obtained from this material (see fig. 8).

m This charge consisted of material, having substantially the same composition, from each of the three previous distillations (see footnote "l").

n The 1.05 liters for this charge consisted of 0.93 liter from the first distillation in column 8 (see fig. 12), and 0.12 liter which was a second lot of $n$-propylcyclohexane supplied by the API Research Project 45.

o This is a third lot of $n$-propylcyclohexane supplied by the API Research Project 45.

D Total volume of the API-Standard sample was 1,260 ml.

a One of two charges of similar material, the second of which was 6.28 liters.

r This charge consisted of material, having substantially the same composition, from each of the two previous distillations (see footnote " $q$ "). 
As demonstrated in the previous reports $[2,3]$, the blending of fractions of distillate for the preparation of material of the highest purity can be done safely only on the basis of freezing points of selected fractions.

\section{Freezing Points, Cryoscopic Constants, and Purity}

Table 2 gives the following information for each of the 18 compounds, except as otherwise indicated: The kind of time-temperature curves, whether freezing or melting, used to determine the freezing point [6]; the freezing point of the actual sample, in air at $1 \mathrm{~atm}$ [6], for both the APIStandard and API-NBS lots; the calculated value of the freezing point for zero impurity [6]; the value of the cryoscopic constant, determined from the lowering of the freezing point on the addition of a known amount of an appropriate impurity [6]; and the resulting calculated amount of impurity in the API-Standard and the API-NBS material.

Grateful acknowledgment is made to the other organizations and individuals listed in section II of this report for their contributions of materials for use in this work.

\section{References}

[1] NBS Tech. News Bul. No. 350 (June 1946).

[2] A. J. Streiff, E. T. Murphy, V. A. Sedlak, C. B. Willingham, and F. D. Rossini, J. Research NBS 37, 331 (1946) RP1752.

[3] A. J. Streiff, E. T. Murphy, J. C. Cahill, H. F. Flanagan, V. A. Sedlak, C. B. Willingham and F. D. Rossini, J. Research NBS 38, 53 (1947) RP1760.

[4] A. R. Glasgow, Jr., E. T. Murphy, C. B. Willingham, and F. D. Rossini, J. Research NBS 37, 141 (1946) RP1734.

[5] C. B. Willingham and F. D. Rossini, J. Research NBS 37, 15 (1946) RP1724.

[6] A. R. Glasgow, Jr., A. J. Streiff, and F. D. Rossini, J. Research NBS 35, 355 (1945) RP1676.

[7] American Petroleum Institute Research Project 44 at the National Bureau of Standards. Selected values of properties of hydrocarbons. Tables $1 \mathrm{z}, 2 \mathrm{z}, 3 \mathrm{z}$, $5 z, 6 z, 7 z$, and $8 z$.

[8] American Petroleum Institute Research Project 44 at the National Bureau of Standards. Selected Values of Properties of Hydrocarbons. Table $7 \mathrm{a}$. 
TABLE 2.-Freezing points and purity of 18 API-Standard and API-NBS hydrocarbons

\begin{tabular}{|c|c|c|c|c|c|c|c|}
\hline \multirow[t]{2}{*}{ Compound $^{a}$} & \multirow[t]{2}{*}{$\begin{array}{c}\text { Kind of } \\
\text { time- temperature } \\
\text { observations } \\
\text { used to } \\
\text { determine } \\
\text { the freezing } \\
\text { point }\end{array}$} & \multicolumn{2}{|c|}{$\begin{array}{l}\text { Freezing } \\
\text { point of } \\
\text { the actual } \\
\text { selected } \\
\text { sample, } \\
\text { in air } \\
\text { at I atmc }\end{array}$} & \multirow[t]{2}{*}{$\begin{array}{l}\text { Freezing point } \\
\text { for zero impurity } \\
\text { in air at I at } \mathrm{m}^{\mathrm{c}}\end{array}$} & \multirow{2}{*}{$\begin{array}{c}\text { Cryoscopic } \\
\text { constant }^{\text {b }} \\
\text { A } \\
\text { deg-1 }\end{array}$} & \multicolumn{2}{|c|}{$\begin{array}{l}\text { Calculated } \\
\text { amount of } \\
\text { impurity } \\
\text { in the } \\
\text { actual } \\
\text { selected } \\
\text { sampled }\end{array}$} \\
\hline & & ${ }^{\circ} \mathrm{C}$ & C & & & mole & percent \\
\hline & & $\begin{array}{c}\text { API- } \\
\text { Standard }\end{array}$ & $\begin{array}{l}\text { API- } \\
\text { NBS }\end{array}$ & & & $\begin{array}{c}\mathrm{API}- \\
\text { Standard }\end{array}$ & $\begin{array}{l}\text { API- } \\
\text { NBS } \\
\end{array}$ \\
\hline $\begin{array}{l}\text { n-Decane } \\
\text { Alkylcyclopentanes }\end{array}$ & $\mathrm{F}$ & 29.680 & -29.677 & $-29.673+0.005$ & ${ }^{e}(0.0585)$ & $0.04 \pm 0.02$ & $0.023 \pm 0.018$ \\
\hline Cyclopentane (B) & $\mathrm{F}$ & -93.902 & -93.887 & $-93.77 \pm 0.04$ & ${ }^{e}(0.00227)$ & $0.030 \pm 0.009$ & $0,026 \pm 0.009$ \\
\hline 1-Methyl-1-e thylcyclopentane & $F$ and $M$ & -143.83 & -143.82 & $-143.800 \pm 0.018$ & 0.0444 & $0.13 \pm 0.08$ & $0.09 \pm 0.08$ \\
\hline cis-I-Methyl-2-ethylcyclopentane & $F$ and $M$ & $-106.05(I)$ & $-106.01(\mathrm{I})$ & $\begin{array}{ll}-105.95 & \pm 0.05(I) \\
-106.62 & \pm 0.05(\mathbb{I D}(u)\end{array}$ & $0.0480(\mathrm{I})$ & $0.48 \pm 0.24$ & $0.29 \pm 0.24$ \\
\hline $\begin{array}{l}\text { Isobutylc yclopentane } \\
\text { Alkylcyclohexanes }\end{array}$ & M & -115.264 & -115.254 & $-115.225 \pm 0.020$ & 0.0405 & $0.16 \pm 0.08$ & $0.12 \pm 0.08$ \\
\hline cis-1,3-Dimethylcyclohexane $e^{f}$ & $M$ & -75.588 & -75579 & $-75.560 \pm 0.015$ & ${ }^{e}(0.0333)$ & $0.09 \pm 005$ & $0.06 \pm 0.05$ \\
\hline trans-1,3-Dimethylcyc lohexane ${ }^{g}$ & M & -90.145 & -90.134 & $-90.100 \pm 0.020$ & ${ }^{\mathrm{e}}(0.035)$ & $0.16 \pm 0.07$ & $0.12 \pm 0.07$ \\
\hline n-Propylcyclohexane & M & -94.924 & -94.918 & $-94.900 \pm 0.015$ & 0.0324 & $0.08 \pm 0.05$ & $0.06 \pm 0.05$ \\
\hline Isopropylcyclohexane & F and $M$ & -89.432 & -89416 & $-89.390 \pm 0.020$ & 0.0373 & $0.16 \pm 0.07$ & $0.10 \pm 0.07$ \\
\hline II,3-Trime thylcyclohexane & $F$ and $M$ & -65.831 & -65.809 & $-65.750 \pm 0.020$ & 0.0260 & $0.21 \pm 0.05$ & $0.15 \pm 0.05$ \\
\hline n-Butylcyclohexane & M & -74.747 & -74.736 & $-74.725 \pm 0.010$ & 0.0385 & $0.08 \pm 0.04$ & $0.042 \pm 0.039$ \\
\hline Isobutylcyclohexane & M & $-94.839(1)$ & $-94.830(1)$ & $\begin{array}{ll}-94.78 & \pm 0.03(I) \\
-95.72 & \pm 0.04(I I)(u)\end{array}$ & $0.029 !(I)$ & $0.17 \pm 0.09$ & $0.15 \pm 0.09$ \\
\hline sec-Butylcyclohexane & & & & & & ${ }^{h}(0.30 \pm 0.20)$ & ${ }^{h}(0.25 \pm 0.20)$ \\
\hline $\begin{array}{c}\text { tert-Butylcyclohexane } \\
\text { Olefins }\end{array}$ & M & -41.173 & -41.170 & $-41.158 \pm 0.010$ & 0.0303 & $0.05 \pm 0.03$ & $0.04 \pm 0.03$ \\
\hline 3,3-Dimethyl-1-butene & $F$ and $M$ & -115.370 & -115.365 & $-115.20 \pm 0.12$ & ${ }^{e}(0.00530)$ & $0.09 \pm 0.06$ & $0.09 \pm 0.06$ \\
\hline $\begin{array}{l}\text { 1-Octene } \\
\text { Diolefins }\end{array}$ & $F$ and $M$ & -101.748 & -101.746 & $-101.710 \pm 0.020$ & 0.0637 & $0.24 \pm 0.13$ & $0.23 \pm 0.13$ \\
\hline $\begin{array}{l}\text { 1,2-Butadiene } \\
\text { Ace tylenes }\end{array}$ & $M$ & -136.209 & -136.204 & $-136.190 \pm 0.012$ & ${ }^{e}(0.04462)$ & $0.08 \pm 0.05$ & $0.06 \pm 0.05$ \\
\hline 2-Butyne & $F$ and $M$ & -32.296 & -32.281 & $-32.260 \pm 0.020$ & ${ }^{\mathrm{e}}(0.0191)$ & $0,069 \pm 0.038$ & $0.041 \pm 0.038$ \\
\hline
\end{tabular}

a $(B)$ following the name of a compound indicates that for the API-NBS series, it is a second (and usually slightly purer) sample of the given compound, the first sample of which is labeled $(A)$. See reference [4].

b $F$ indicates freezing and $M$ indicates melting. See reference [6] for experimental details and the definition of the cryoscopic constant.

- When a given hydrocarbon has more than one crystalline form, the several forms will be labeled I, II, and III, in order of decreasing temperature of fusion (or freezing point). Forms other than I will be, at their respective freezing points, in metastable equilibrium with the underconled liquid, but will be unstable with respect to transition to some other solid form at the same temperature and pressure ( $1 \mathrm{~atm})$. This is indicated by a letter $u$ in parentheses following the Roman numeral. d The values in this column, except as otherwise indicated, were calculated as described in reference [6], using the values of the cryoscopic constants and freezing points for zero impurity given in the preceding columns.

e Not determined in this investigation. From the " $z$ " tables of the American Petroleum Institute Research Project 44 [7].

1 This isomer, formerly labeled "trans", has the following properties: Boiling point at $1 \mathrm{~atm}, 120.09^{\circ} \mathrm{C}$; refractive index, $n_{D}$ at $25^{\circ} \mathrm{C}, 1.4206$; density at $25^{\circ} \mathrm{C}, 0.7620 \mathrm{~g} / \mathrm{ml}[8]$.

g This isomer, formerly labeled "cis", has the following properties: boiling noint at $1 \mathrm{~atm}, 124.45^{\circ} \mathrm{C}$; refractive index, $n_{D}$ at $25^{\circ} \mathrm{C}, 1.4284$; density at $25^{\circ}$ C, $0.7806 \mathrm{~g} / \mathrm{ml}[8]$.

b Estimated by analogy with isomers subjected to similar purification. 


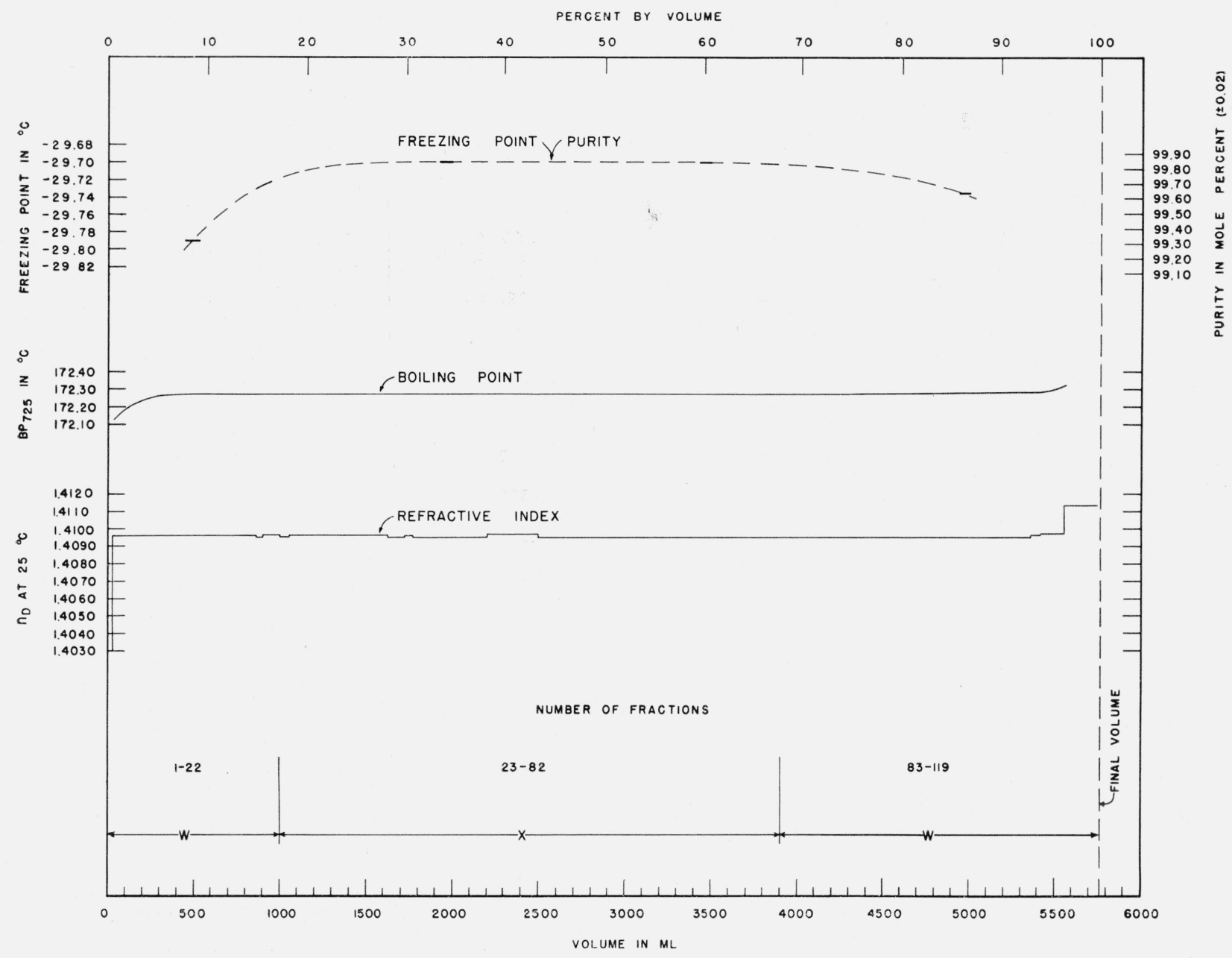

Figure 1.-Results of the first distillation of $n$-decane.

Regular distillation at $725 \mathrm{~mm} \mathrm{Hg}$ in still $14(7 / 27 / 45$ to $8 / 18 / 45)$. This is one of two similar distillations. 


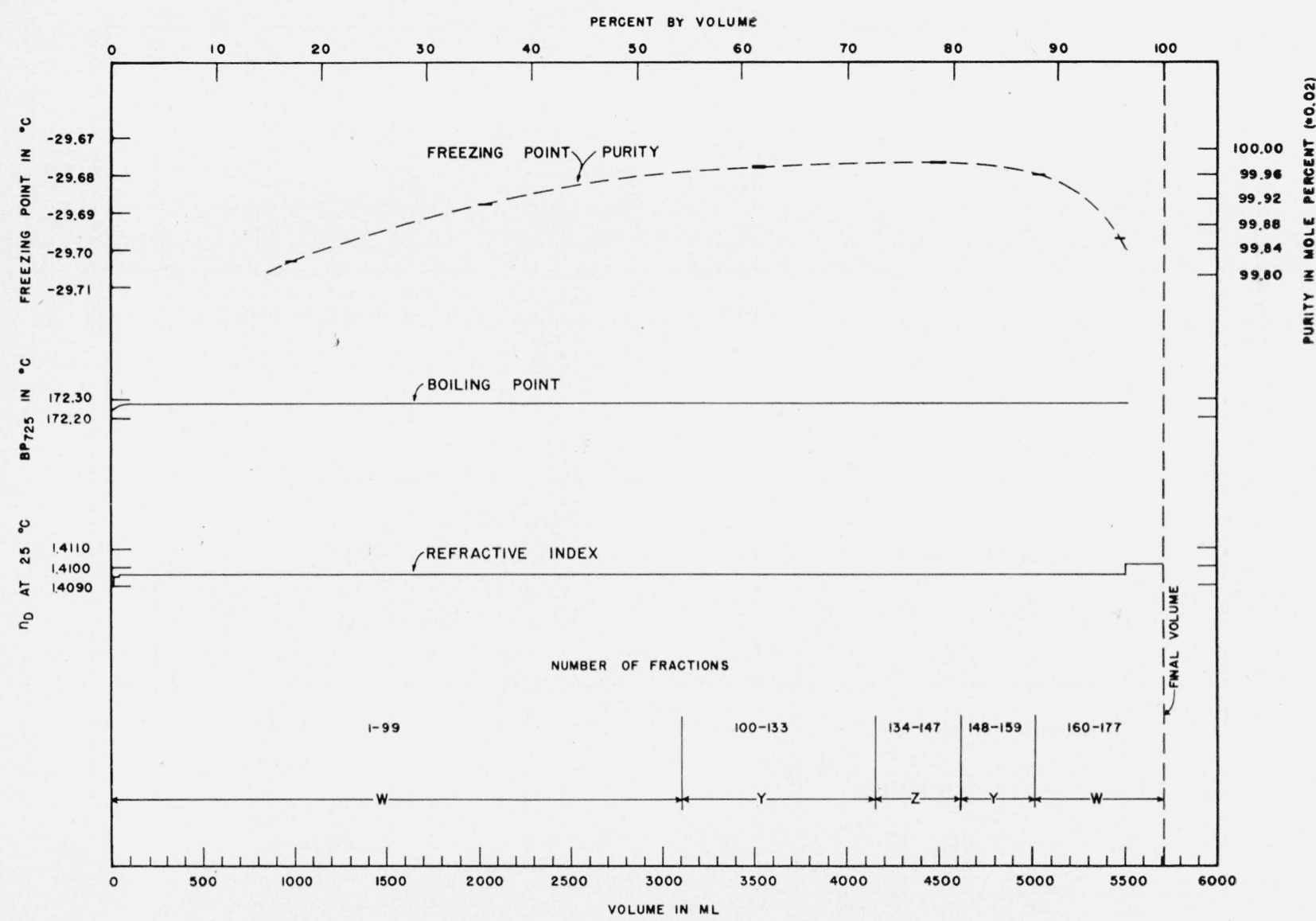

FIGURE 2.-Results of the second and final distillation of $n$-decane.

Regular distillation at $725 \mathrm{~mm} \mathrm{Hg}$ in still 7 (9/18/45 to 10/22/45). See footnote "i" of table 1 . 


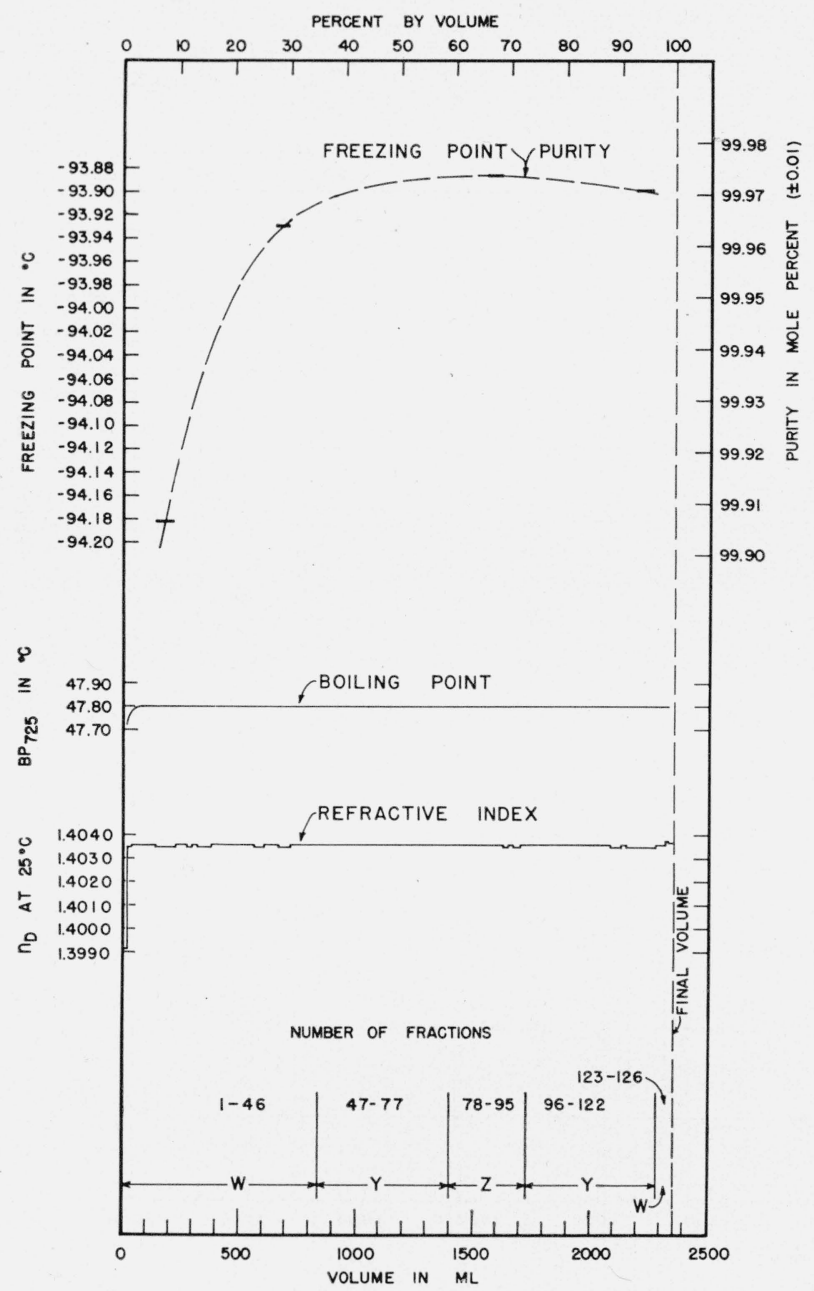

FIgURe 3.-Results of the first and only distillation of cyclopentane.

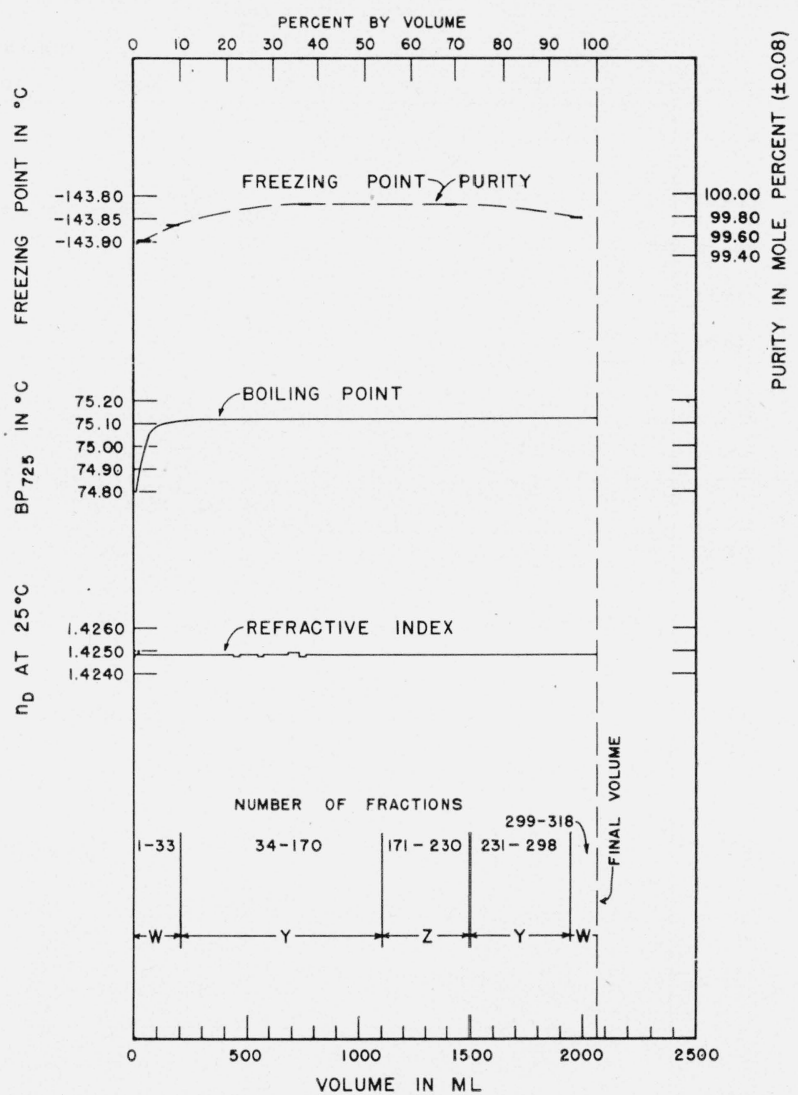

FIGURE 4.-Results of the first and only distillation of 1-methyl-1-ethylcyclopentane.

Azeotropic distillation with ethanol at $725 \mathrm{~mm} \mathrm{Hg}$ in still $4(2 / 25 / 46$ to $4 / 22 / 46)$.

Regular distillation at $725 \mathrm{~mm} \mathrm{Hg}$ in still $2(1 / 29 / 46$ to $3 / 25 / 46)$. 


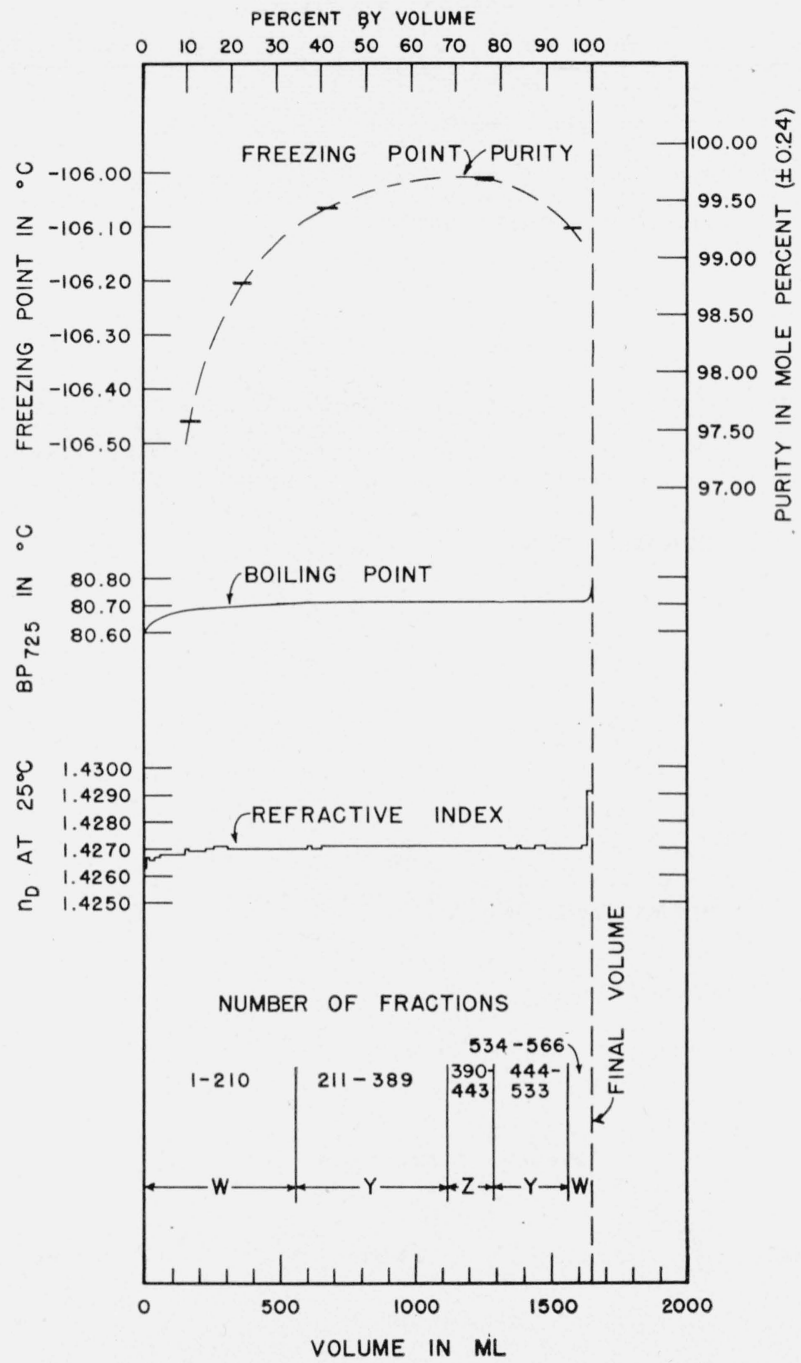

Figure 5.-Results of the first and only distillation of cis-1-methyl-2-ethylcyclopentane.

Azeotropic distillation with isopropanol at $725 \mathrm{~mm} \mathrm{Hg}$ in still 4 (5/22/46 to $8 / 28 / 46)$, 


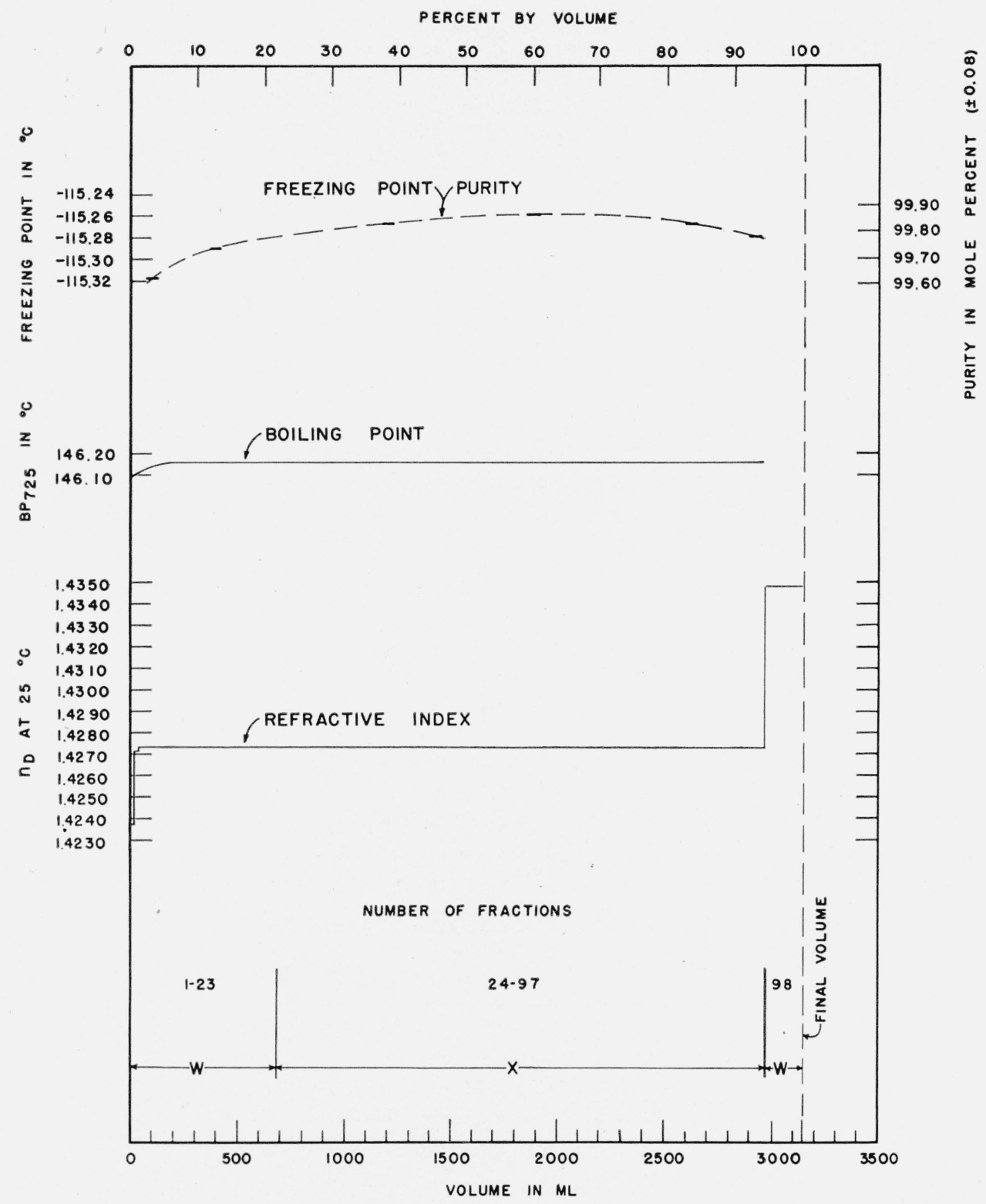

FIGURE 6.-Results of the first distillation of isobutylcyclopentane. Regular distillation at $725 \mathrm{~mm} \mathrm{Hg}$ in still $13(12 / 7 / 45$ to $12 / 28 / 45)$. 


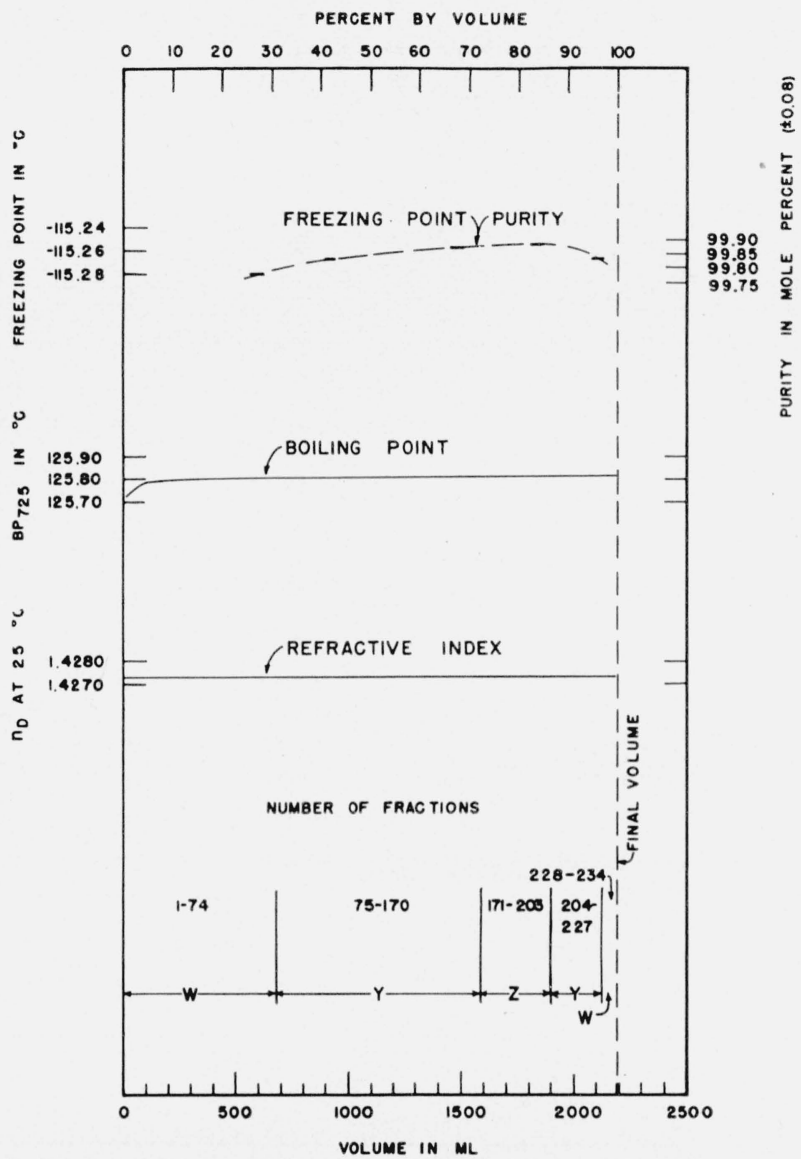

FIGURE 7.-Results of the second and final distillation of isobutylcyclopentane.

A zeotropic distillation with ethylene glycol monoethyl ether at $725 \mathrm{~mm} \mathrm{Hg}$ in still $10(9 / 3 / 46$ to $10 / 14 / 46)$. 


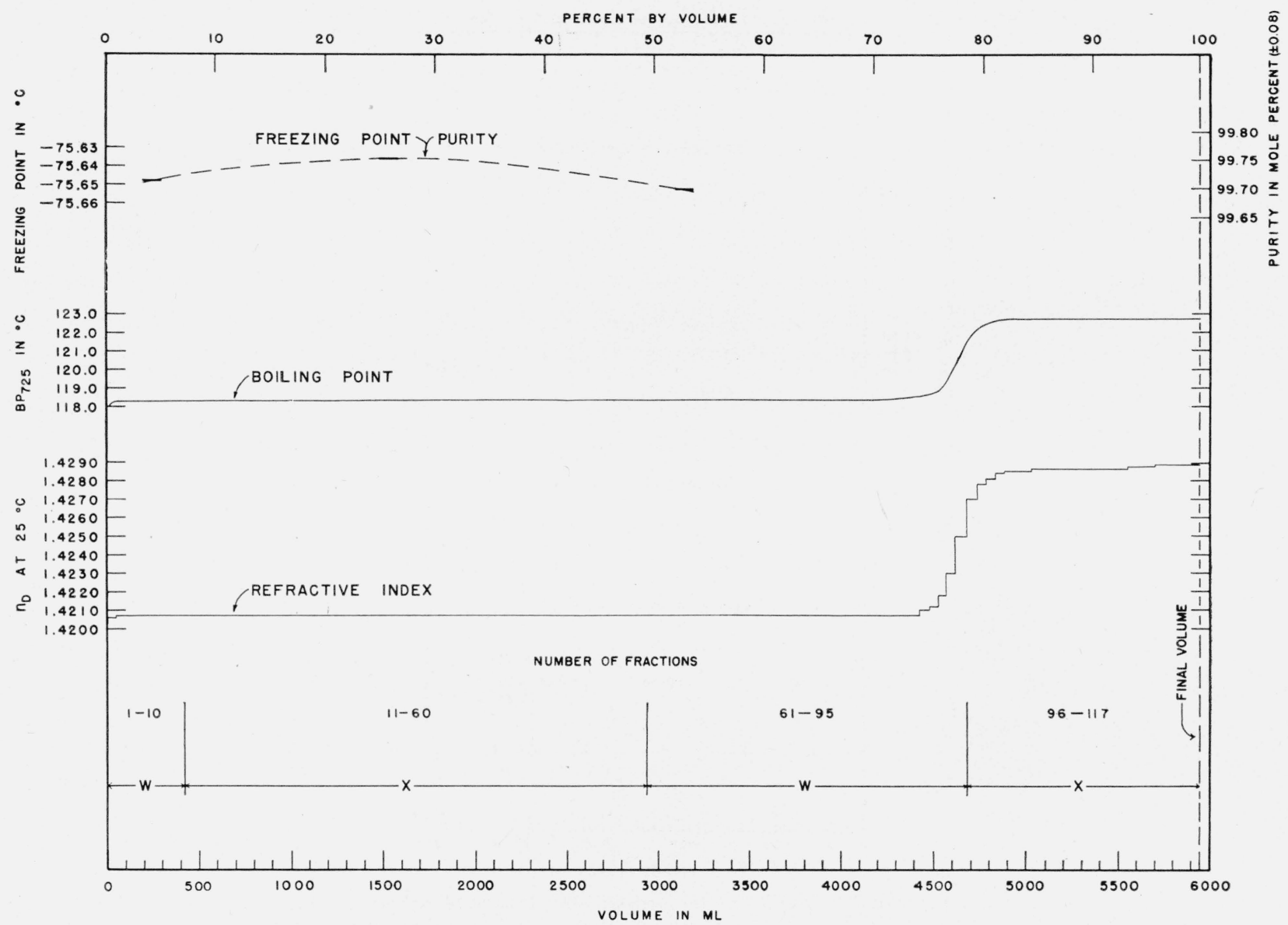

FIGURE 8.- Results of the first distillation of cis and trans-1, 8-dimethylcyclohexane.

Regular distillation at $725 \mathrm{~mm} \mathrm{Hg}$ in still 15 (3/27/46 to 4/17/46). One of three distillations of similar material. See footnote "ll" of table 1. Fractions 11 to 60 were redistilled to obtain cis-1,3-dimethyleyclohexane (see fig. 9 and footnote "f" of table 2). Fractions 96 to 117 were redistilled to obtain trans1, 3-dimethylcyclohexane (see fig. 11 and footnote "g" of table 2). 


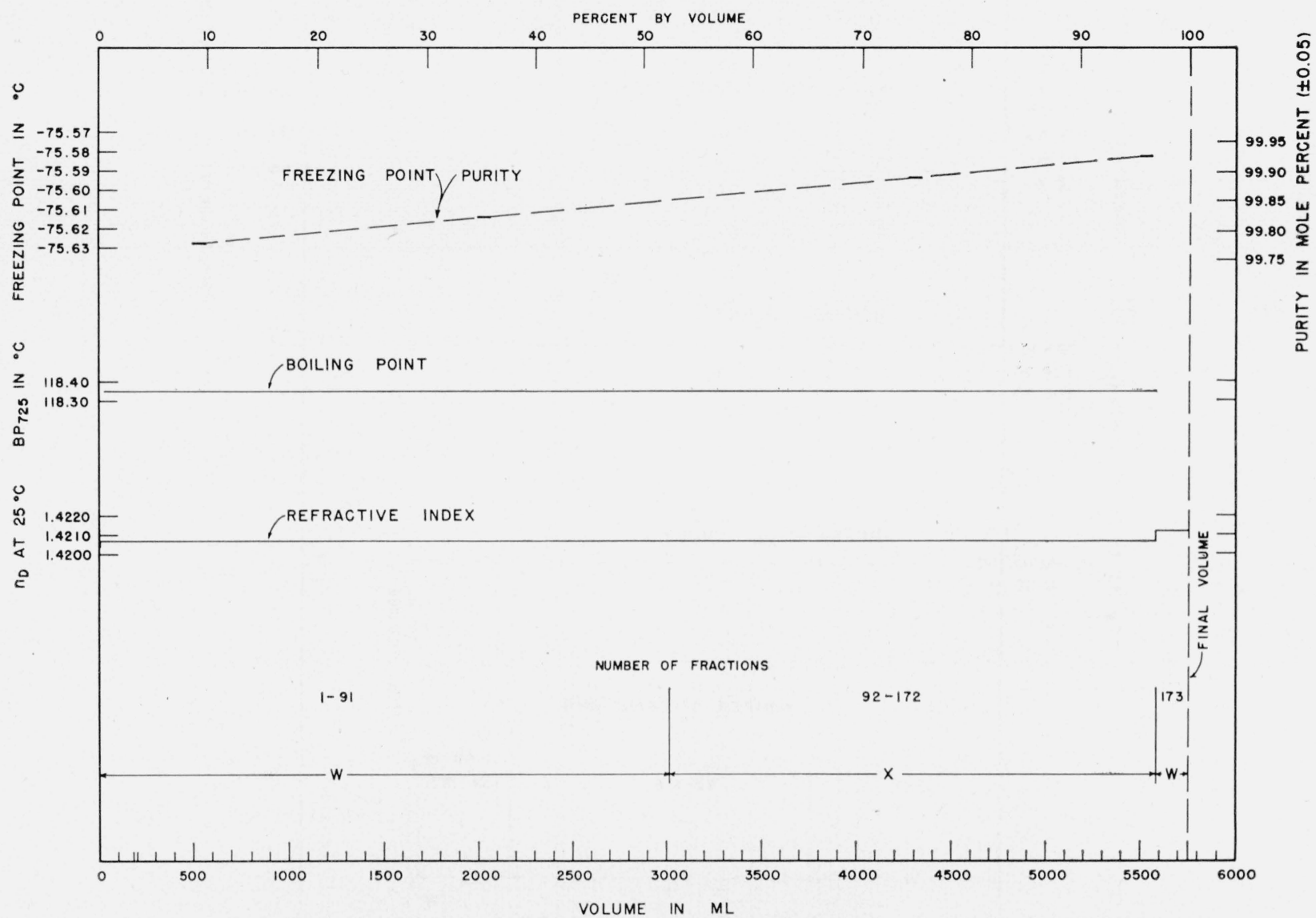

Figure 9.-Results of the second distillation of cis-1,3-dimethylcyclohexane (see footnote "f " of table 2).

Regular distillation at $725 \mathrm{~mm} \mathrm{Hg}$ in still 7 (5/3/46 to 6/3/46). 


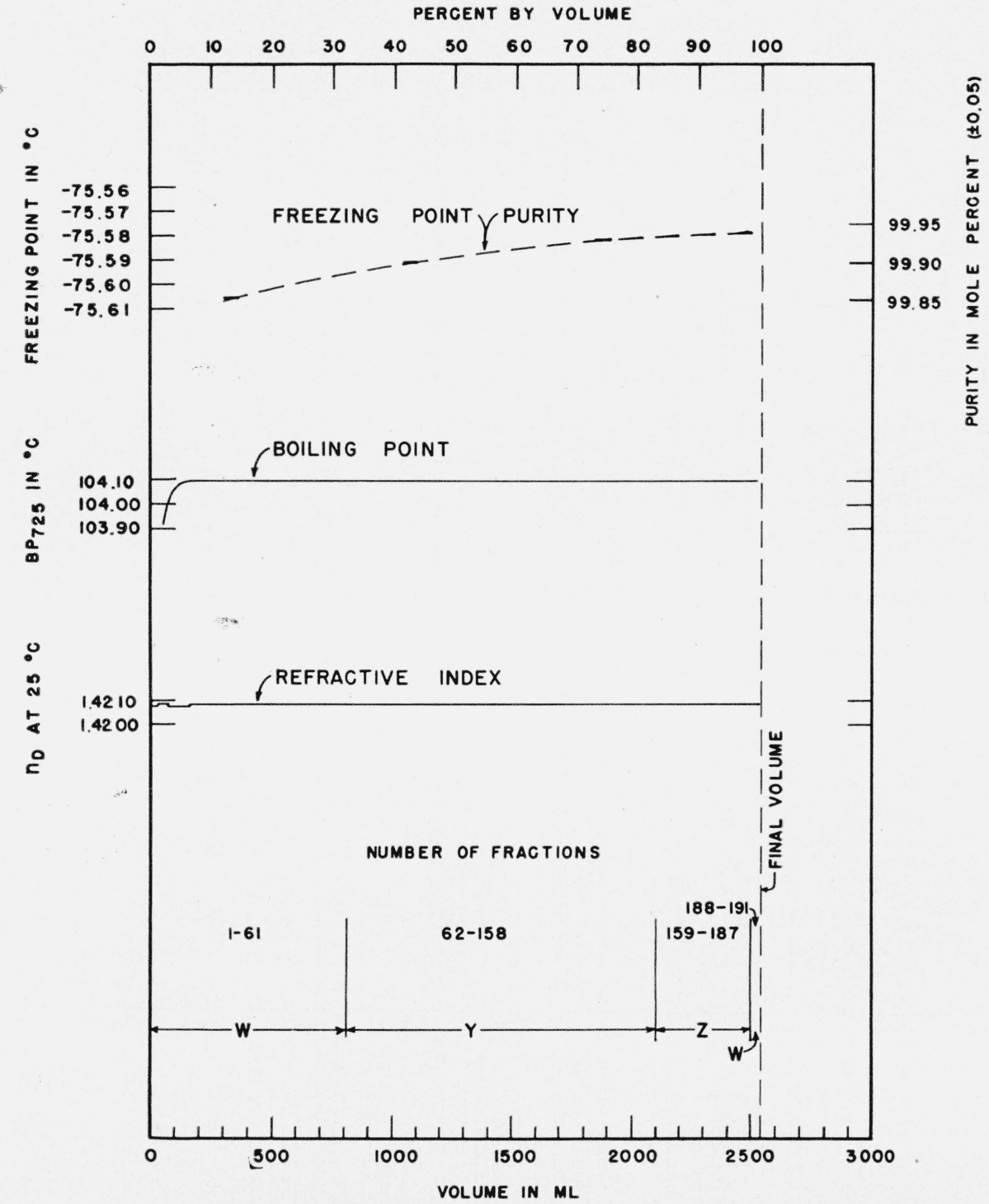

FIGURE 10.-Results of the third and final distillation of cis-1,3-dimethylcyclohexane (see footnote " $f$ " of table $\mathbf{2}$ ). Azeotropic distillation with ethylene glycol monomethyl ether at $725 \mathrm{~mm} \mathrm{Hg}$ in still $15 \mathrm{~A}$ (6/29/46 to 8/5/46). 


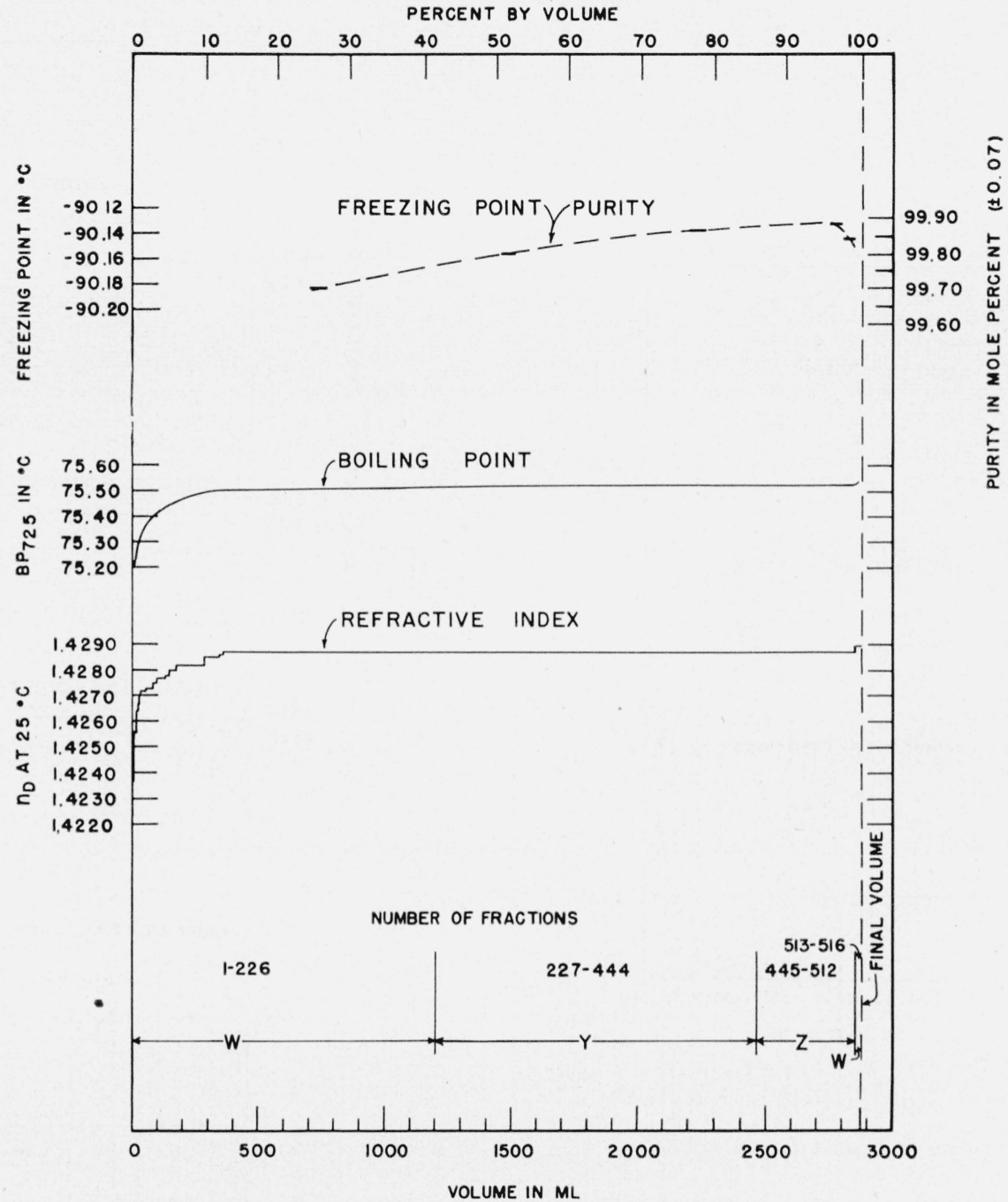

FIGURE 11.-Results of the second and final distillation of trans-1,3-dimethylcyclohexane (see footnote " $g$ " of table 2). A zentropic distillation with ethanol at $725 \mathrm{~mm} \mathrm{Hg}$ in still $9(5 / 4 / 46$ to $8 / 5 / 46)$. 


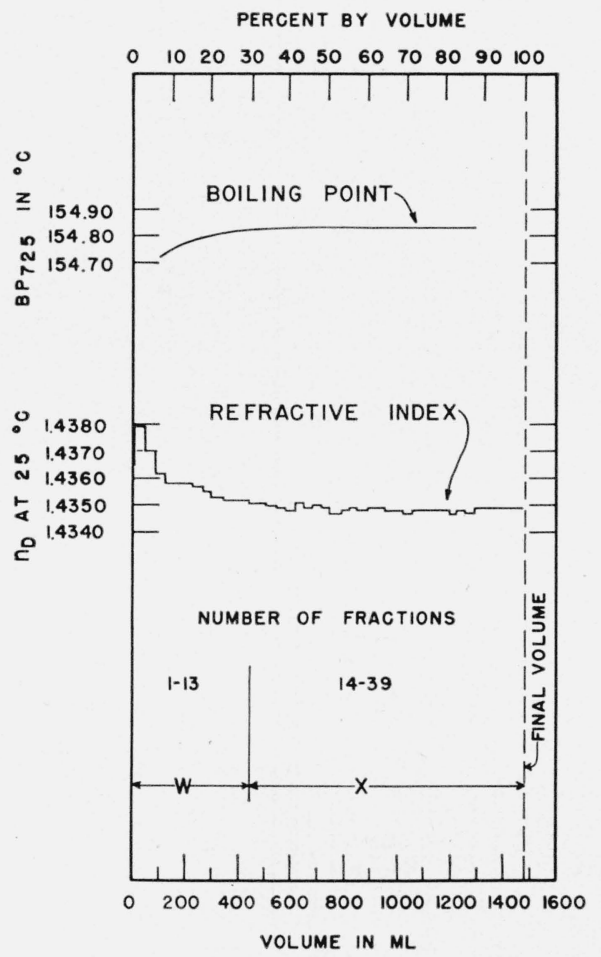

FIGURE 12.-Results of the first distillation of n-propylcyclohexane.

Regular distillation at $725 \mathrm{~mm} \mathrm{Hg}$ in still 8 (5/5/44 to 5/11/44).

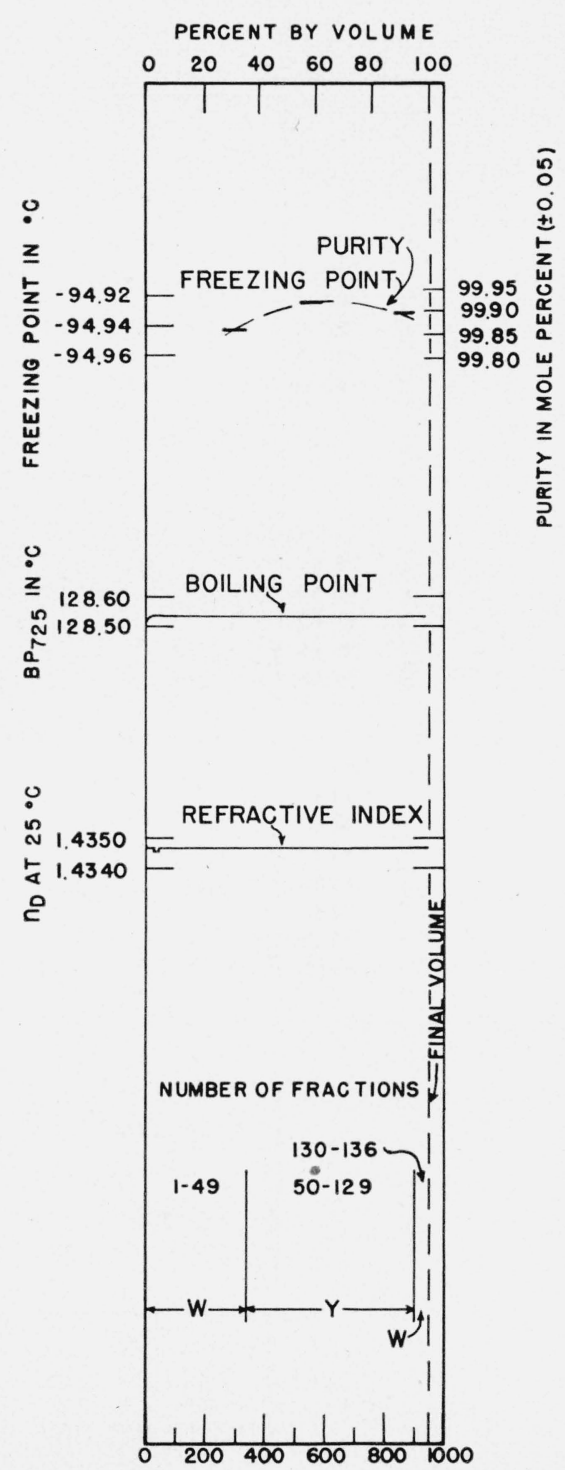

FIGURE 13.-Results of the second distillation of n-propylcyclohexane.

Azeotropic distillation with ethylene glycol monoethyl ether at $725 \mathrm{~mm}$ $\mathrm{Hg}$ in still $9(6 / 14 / 44$ to $7 / 10 / 44)$. 


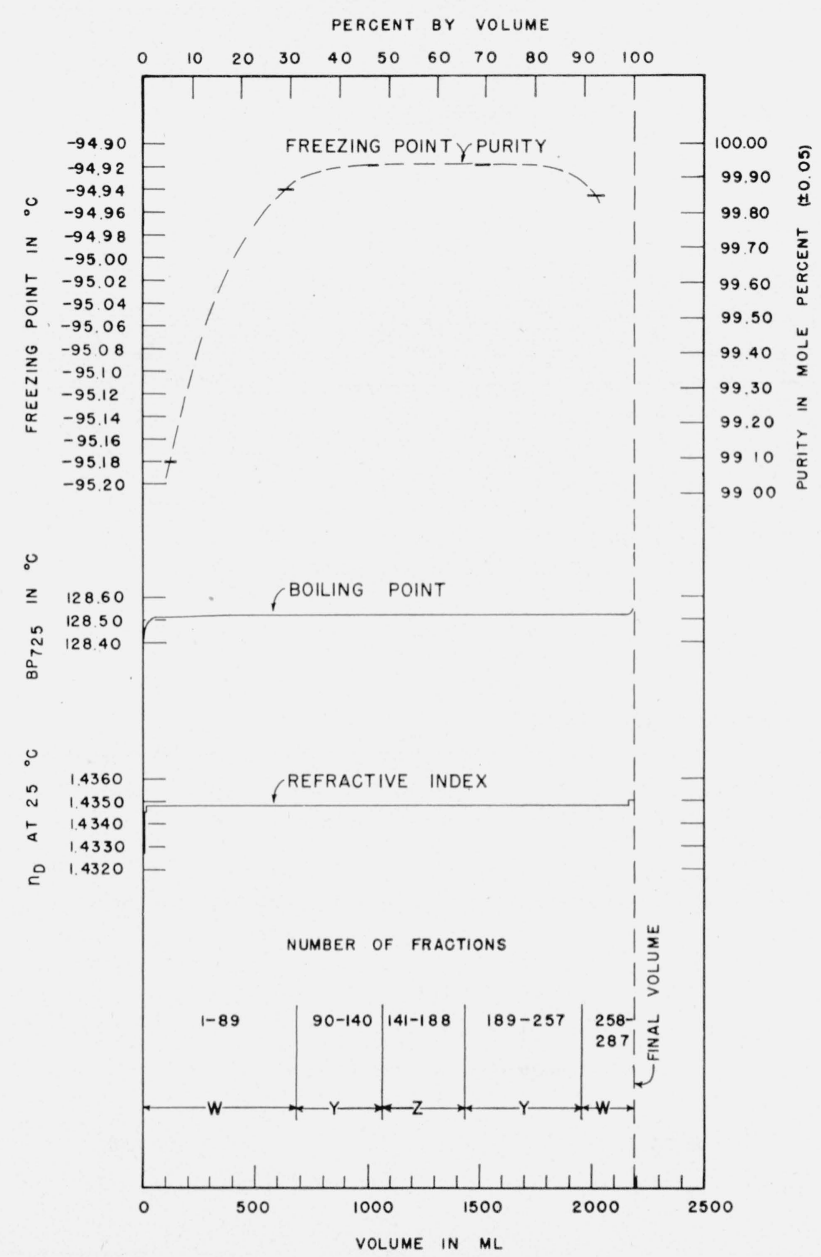

FIGURE 14.-Results of the third distillation of n-propylcyclohexane.

Azeotropic distillation with ethylene glycol monoethyl ether at:725 mm $\mathrm{Hg}$ in still 9 (3/13/46 to 5/3/46). See footnote "o" of table 2. 


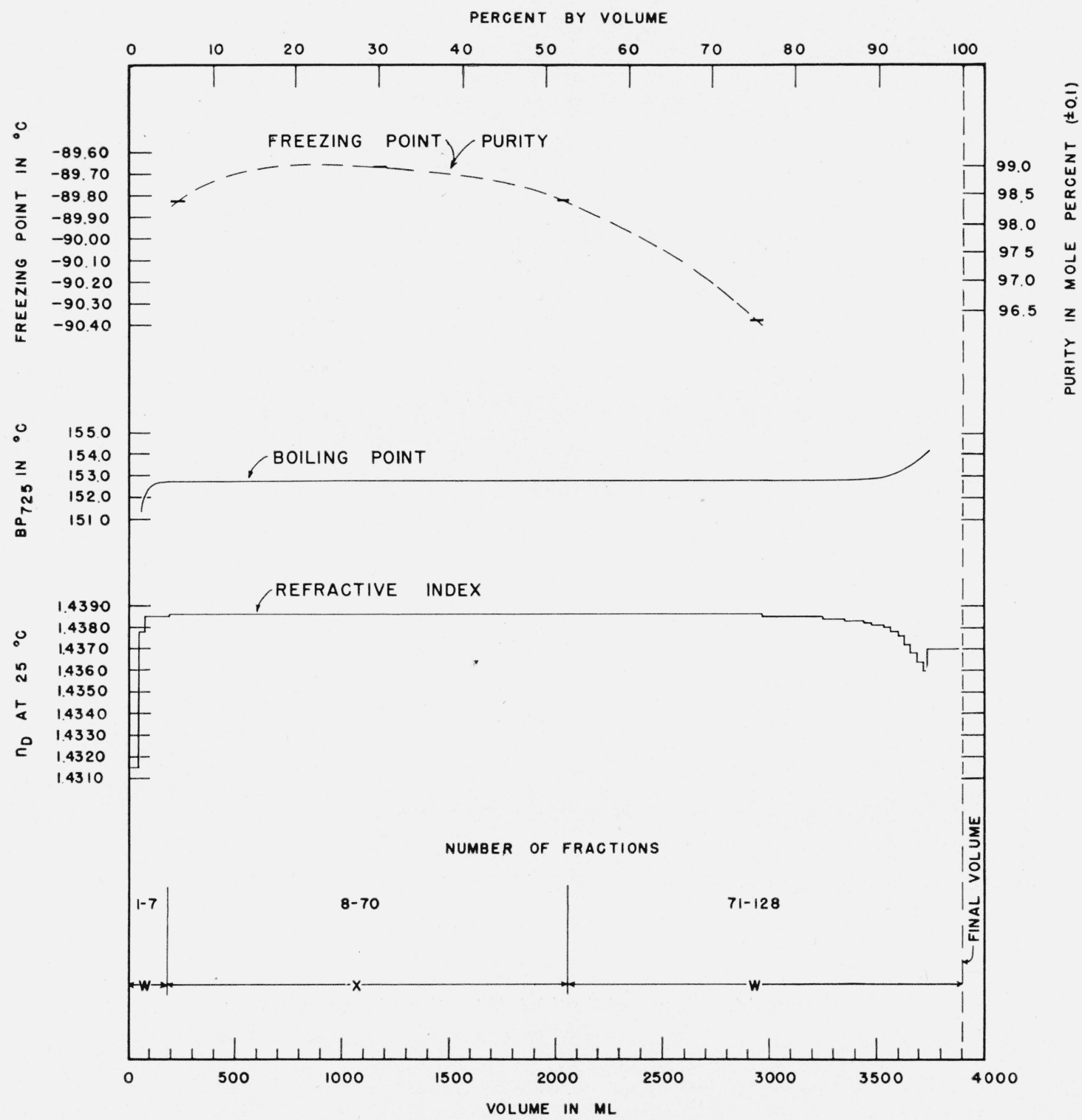

FIGURE 15.-Results of the first distillation of isopropylcyclohexane. Regular distillation at $725 \mathrm{~mm} \mathrm{Hg}$ in still 8 (10/18/45 to 11/12/45). 


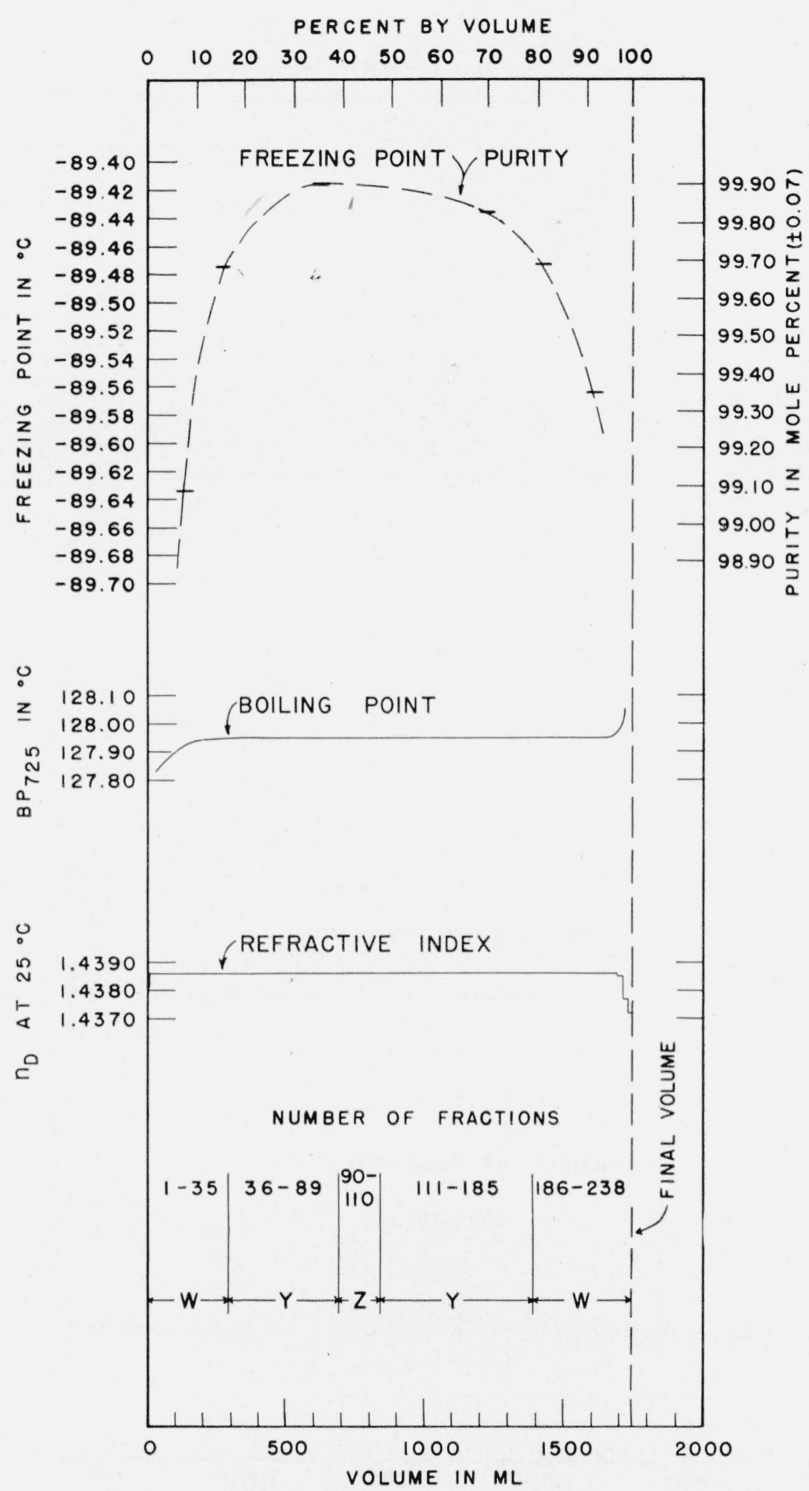

FIGURE 16.-Results of the second and final distillation of isopropylcyclohexane.

Azeotropic distillation with ethylene glycol monoethyl ether at $725 \mathrm{~mm}$ $\mathrm{Hg}$ in still $10(3 / 2 / 46$ to $4 / 12 / 46)$. 


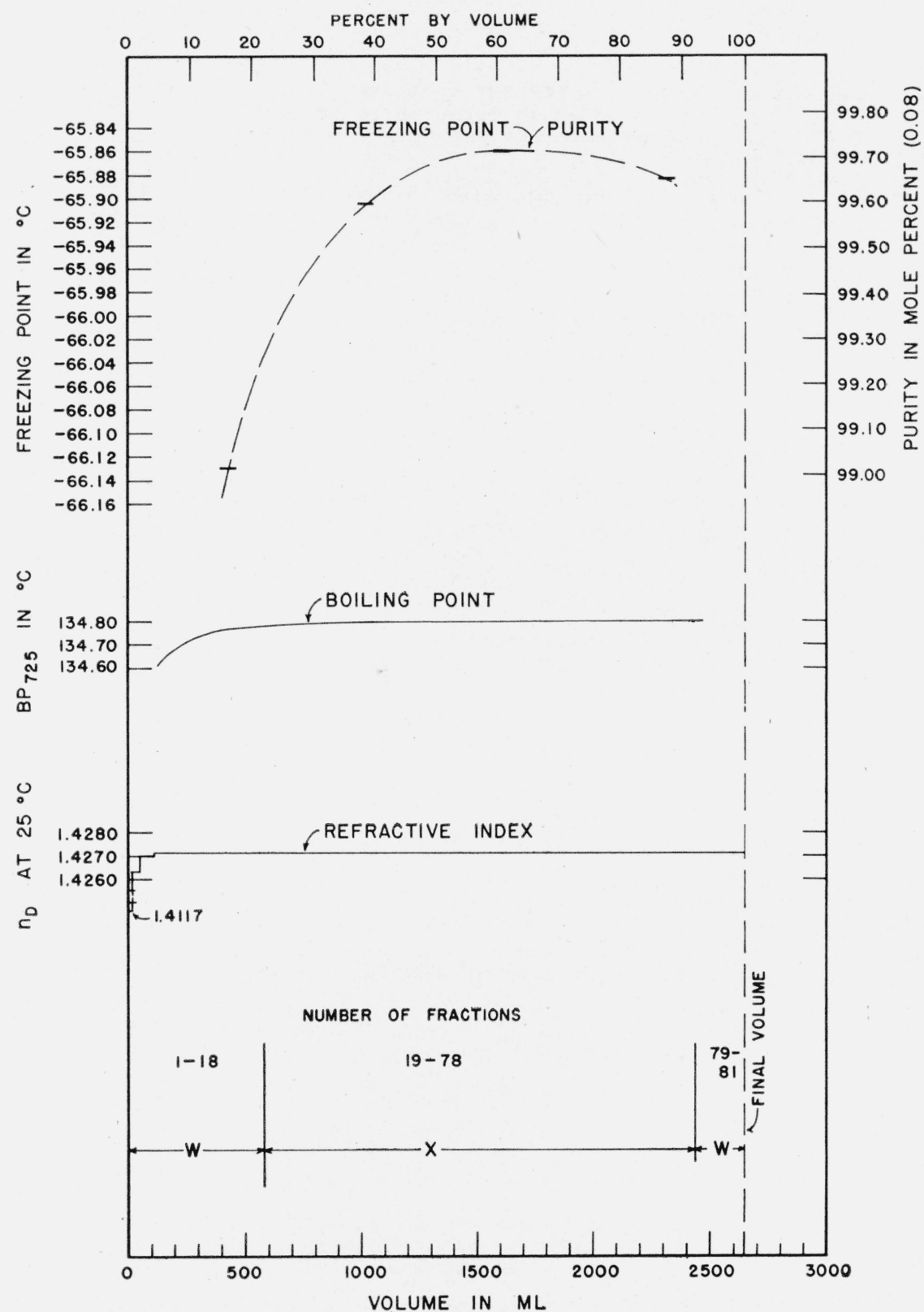

FIGURE 17.-Results of the first distillation of 1,1,3-trimethylcyclohexane. Regular distillation at $725 \mathrm{~mm} \mathrm{Hg}$ in still 7 (10/25/45 to 11/9/45). 

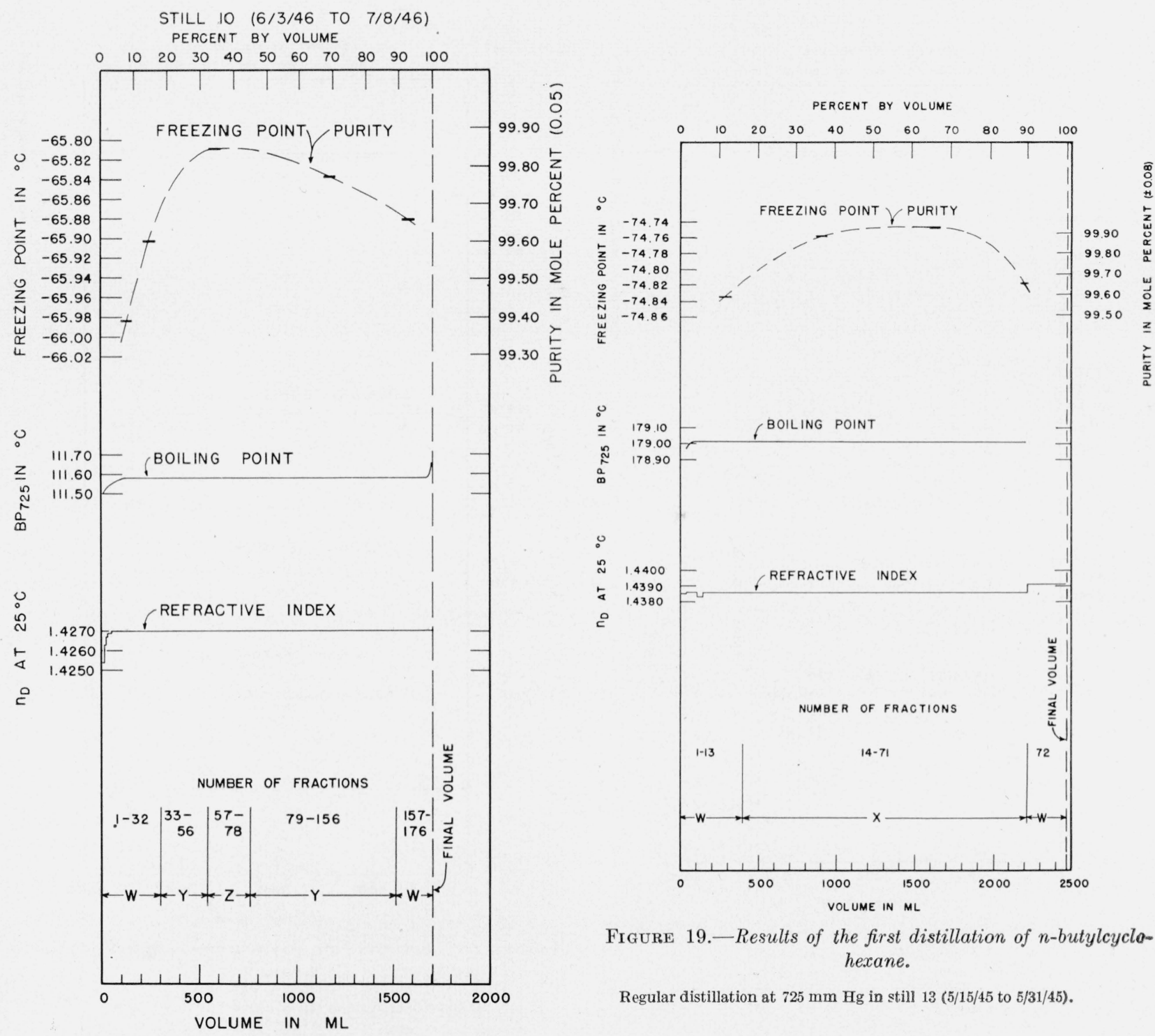

Figure 19.-Results of the first distillation of n-butylcyclohexane.

Regular distillation at $725 \mathrm{~mm} \mathrm{Hg}$ in still $13(5 / 15 / 45$ to $5 / 31 / 45)$.

FIGURE 18.-Results of the second and final distillation of 1,1,3-trimethylcyclohexane.

Azeotropic distillation with ethylene glycol monomethyl ether at $725 \mathrm{~mm}$ $\mathrm{Hg}$ in still $10(6 / 3 / 46$ to $7 / 8 / 49)$ 


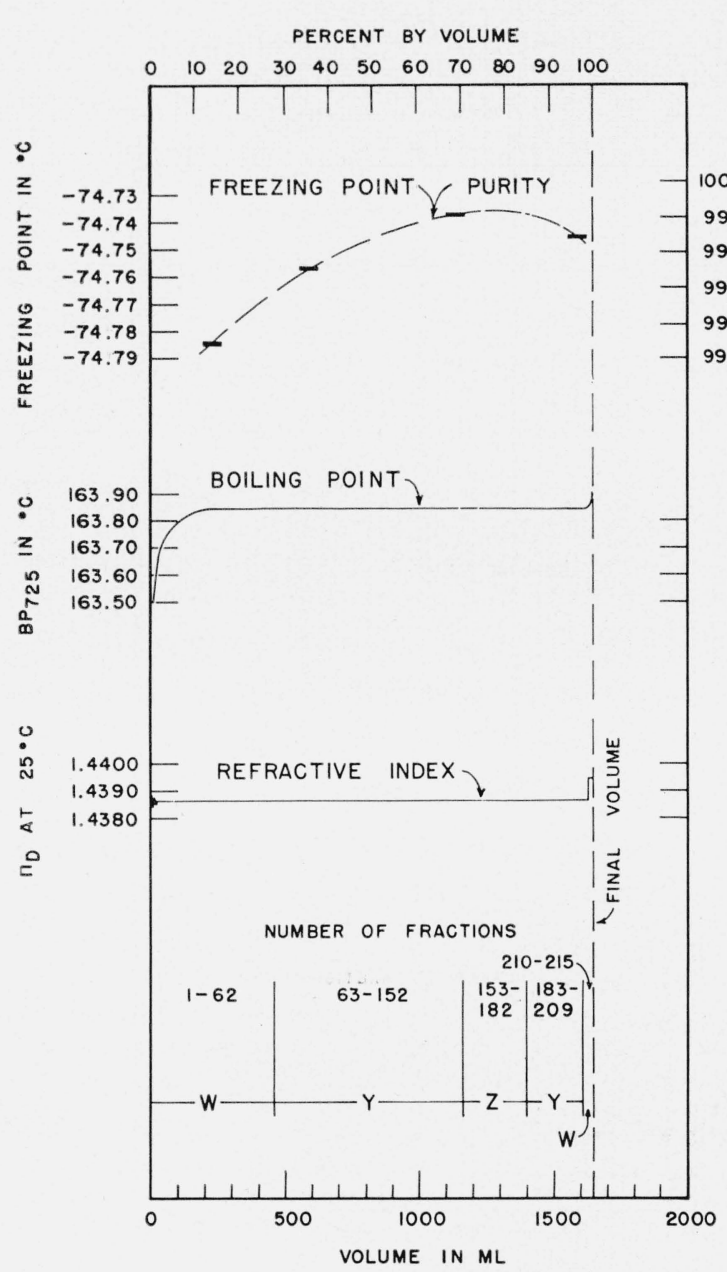

FIGURE 20.-Results of the second and final distillation of n-butylcyclohexane.

Azeotropic distillation with ethylene glycol monohutyl ether at $725 \mathrm{~mm}$ $\mathrm{Hg}$ in still $10(7 / 23 / 46$ to $8 / 31 / 46)$.

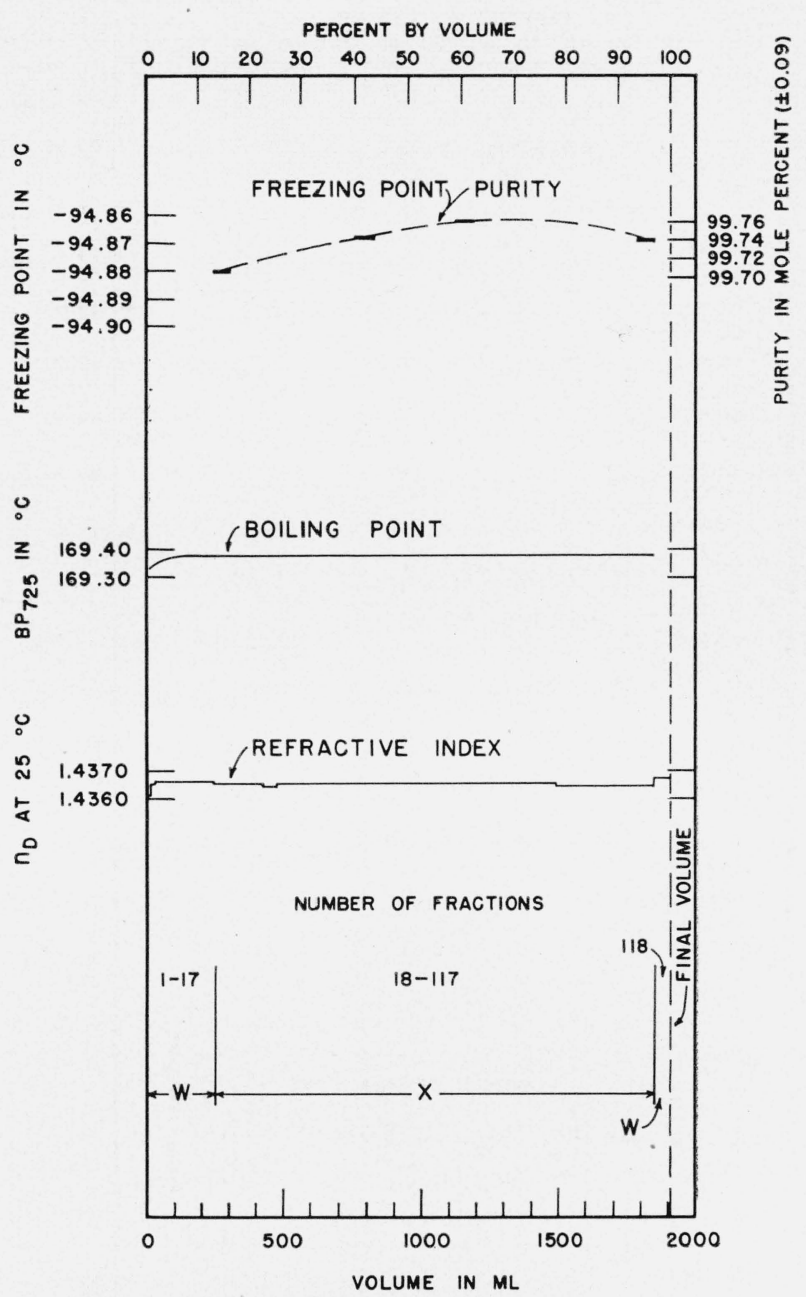

FIGURE 21.-Results of the first distillation of isobutylcyclohexane.

Regular distillation at $725 \mathrm{~mm} \mathrm{Hg}$ in still $2(12 / 7 / 45$ to $1 / 21 / 46)$. 


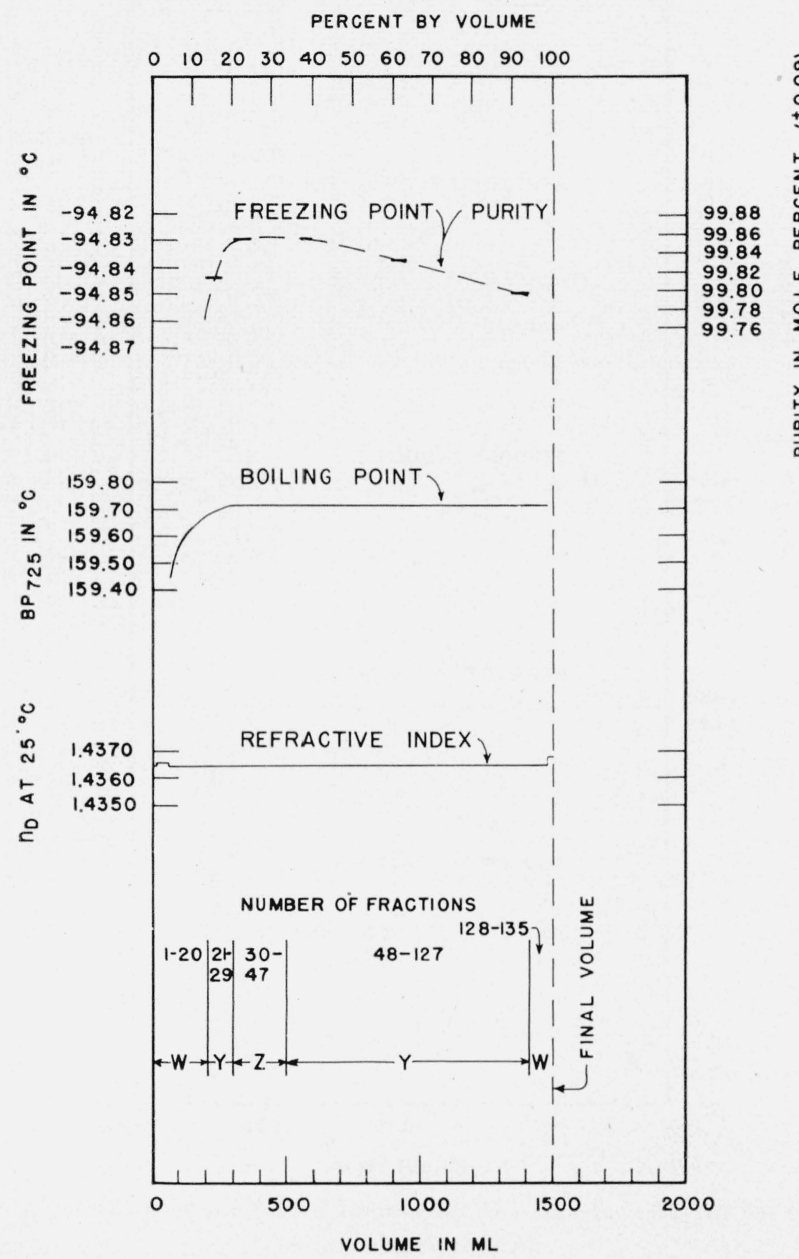

Figure 22.-Results of the second and final distillation of isobutylcyclohexane.

Azeotropic distillation with ethylene glycol monobutyl ether at $725 \mathrm{~mm}$ $\mathrm{Hg}$ in still $11 \mathrm{~A}(7 / 25 / 46$ to $8 / 20 / 46)$.

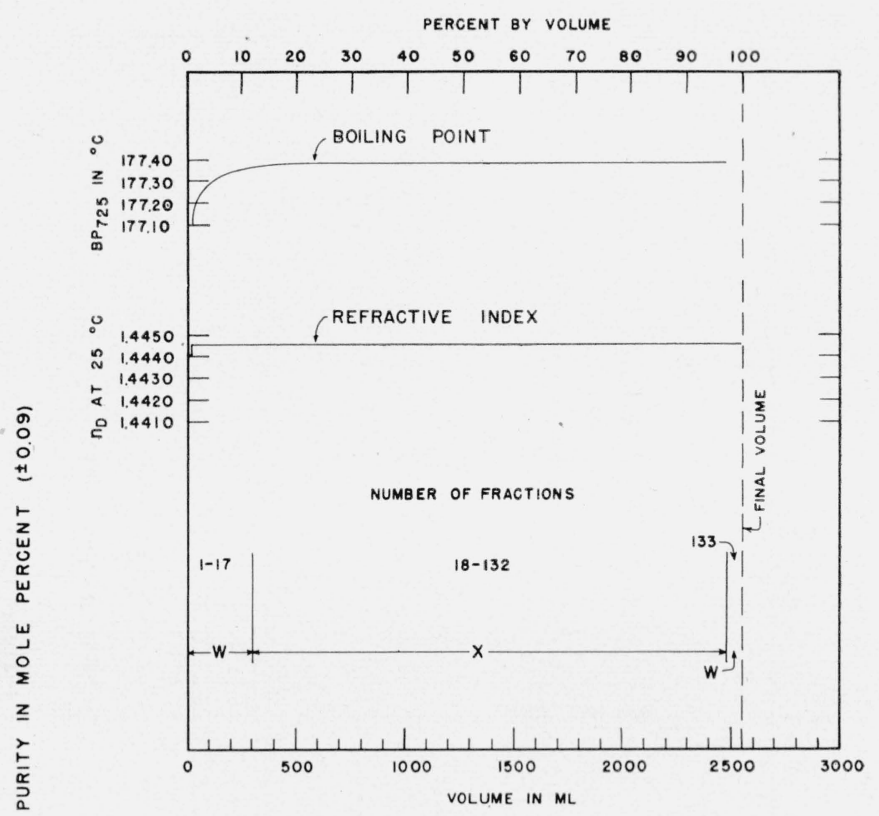

Figure 23.-Results of the first distillation of sec-butylcyclohexane.

Regular distillation at $725 \mathrm{~mm} \mathrm{Hg}$ in still $12(6 / 3 / 46$ to $6 / 27 / 46)$.

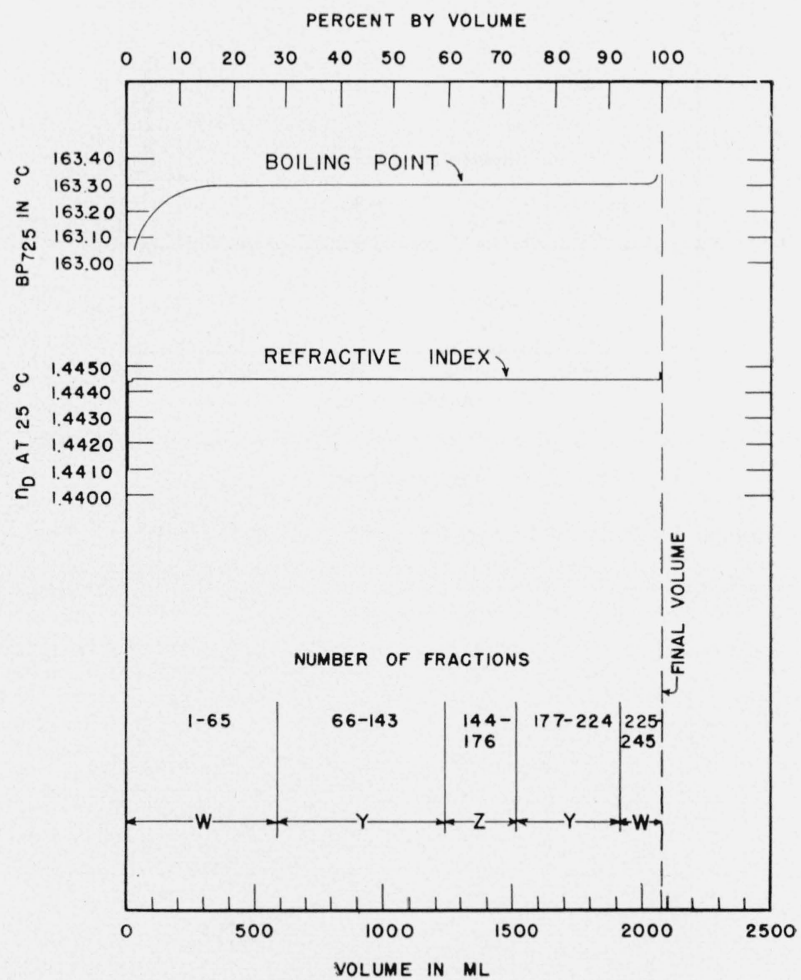

Figure 24.- Results of the second and final distillation of sec-butylcyclohexane.

Azeotropic distillation with ethylene glycol monobutyl ether at $725 \mathrm{~mm}$ $\mathrm{Hg}$ in still $11 \mathrm{~A}(8 / 21 / 46$ to $10 / 4 / 46)$. 


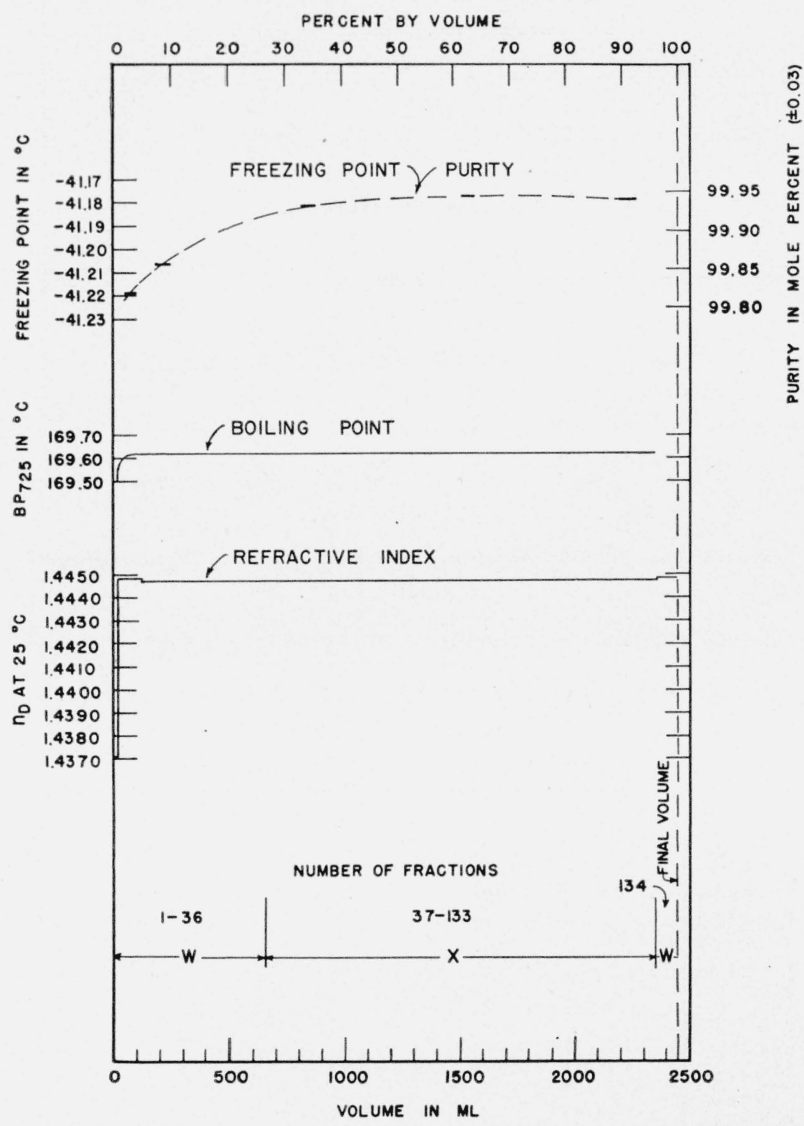

FIGURE 25.-Results of the first distillation of tert-butylcyclohexane.

Regular distillation at $725 \mathrm{~mm} \mathrm{Hg}$ in still $12(1 / 2 / 46$ to $1 / 29 / 46)$.

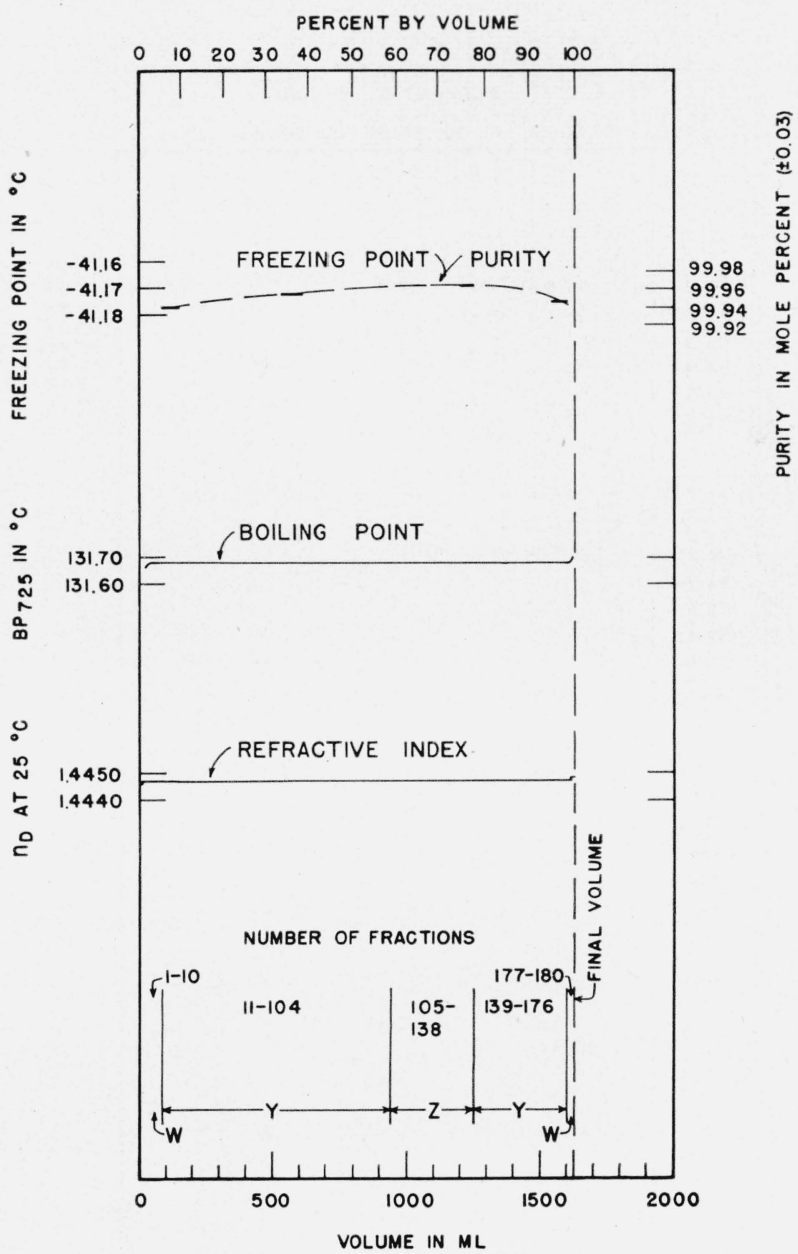

FIGURE 26.-Results of the second and final distillation of tert-butylcyclohexane.

Azeotropic distillation with ethylene glycol monoethyl ether at $725 \mathrm{~mm} \mathrm{Hg}$ in still $8(3 / 15 / 46$ to $4 / 18 / 46)$. 


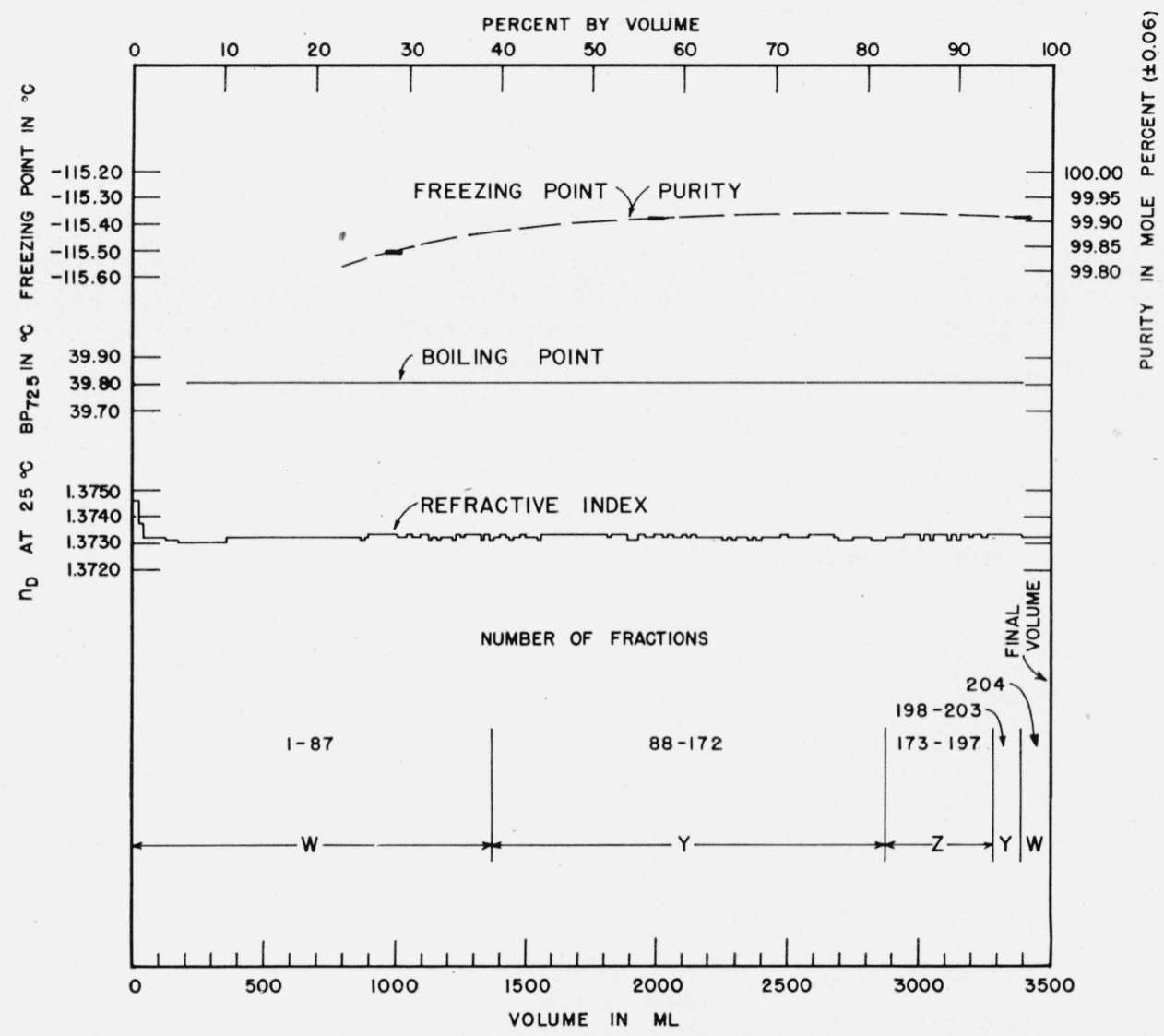

FIGURE 27.-Results of the first and only distillation of 3,3-dimethyl-1-butene. Regular distillation at $725 \mathrm{~mm} \mathrm{Hg}$ in still 9 (12/27/44 to 2/15/45). 


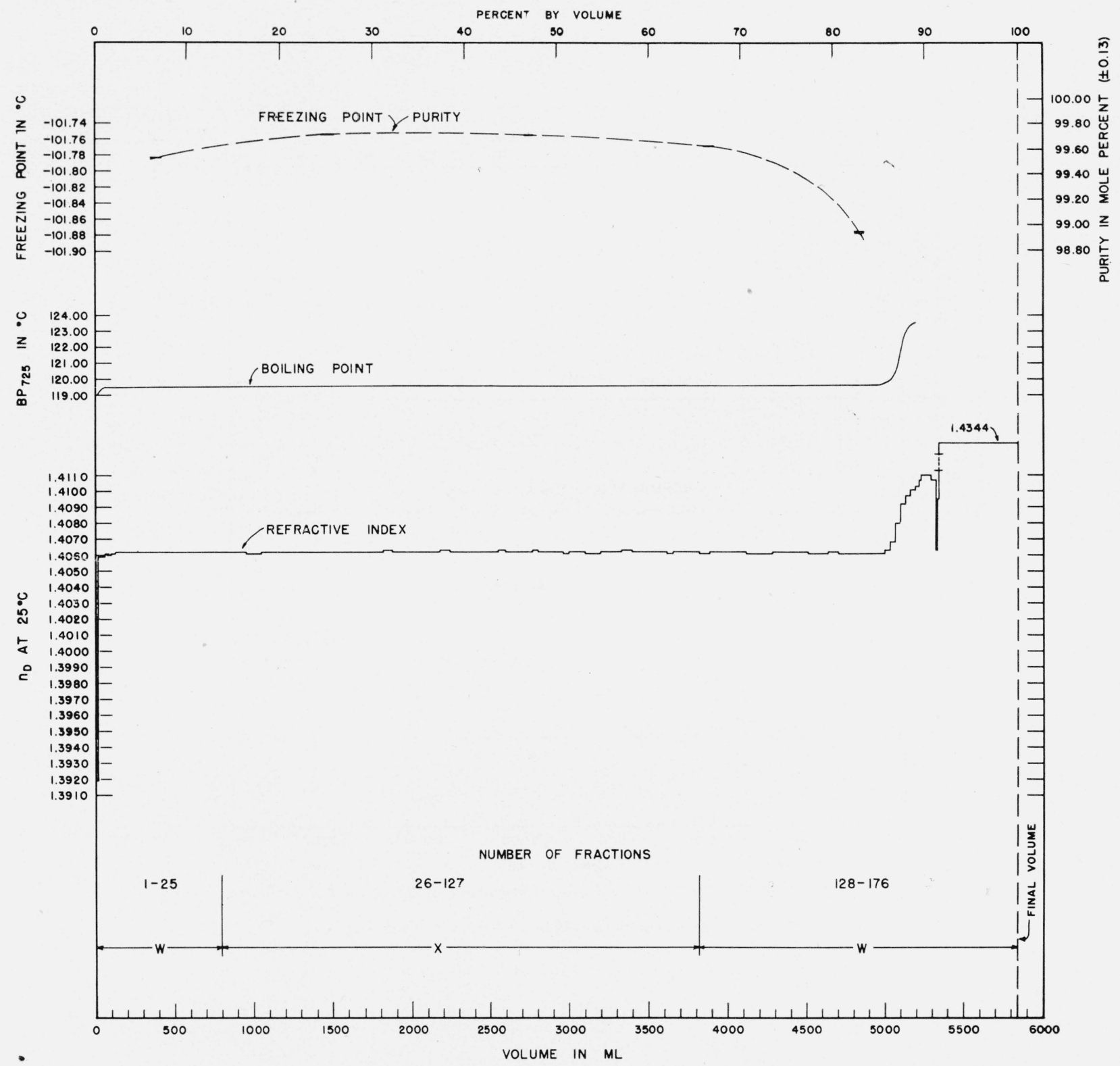

FIGURE 28.-Results of the first distillation of 1-octene.

Regular distillation at $725 \mathrm{~mm} \mathrm{Hg}$ in still $13(1 / 3 / 46$ to $2 / 4 / 46)$. This is one of two distillations of similar material. 


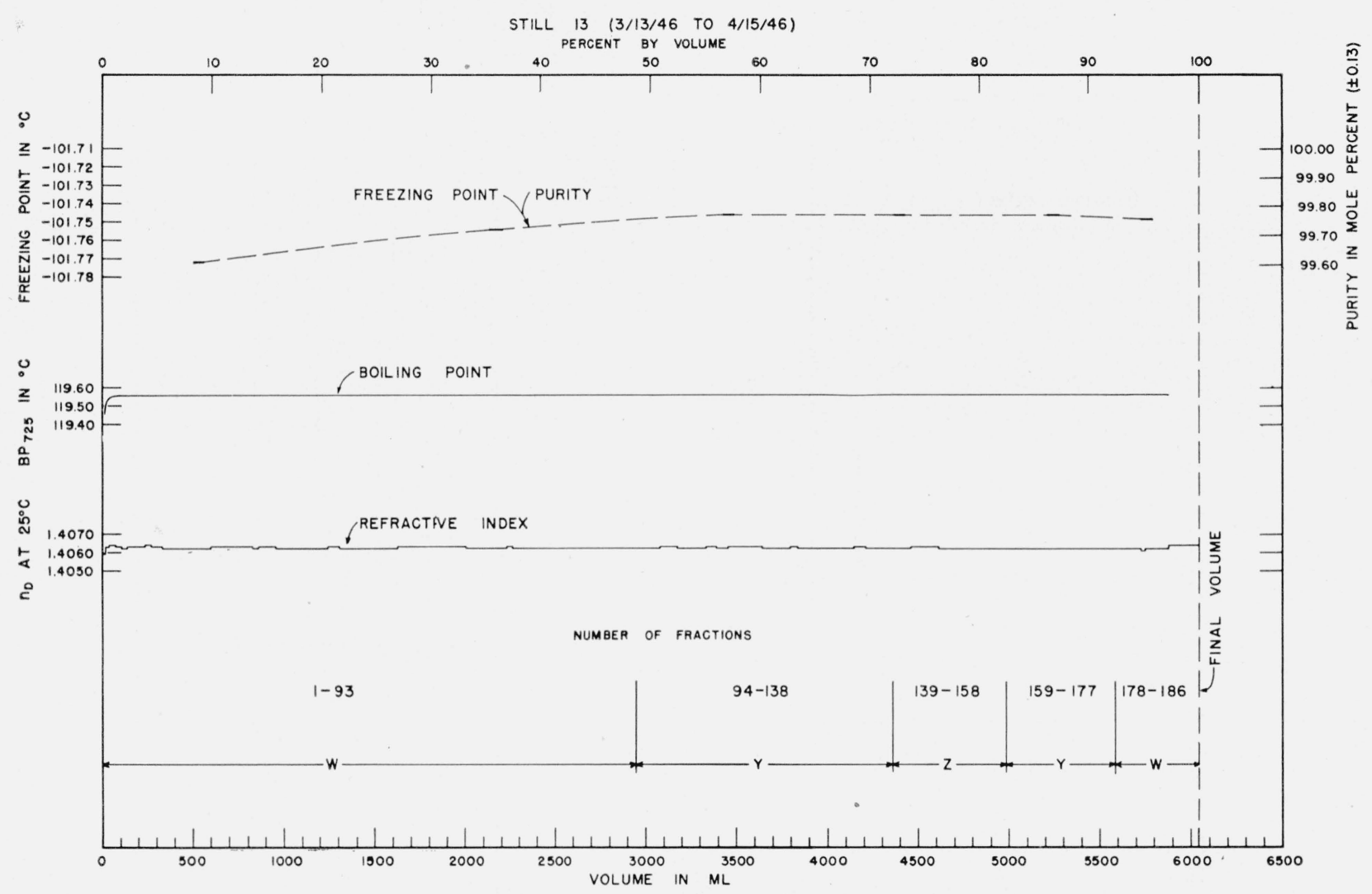

Figure 29.-Results of the second and final distillation of 1-octene.

Regular distillation at $725 \mathrm{~mm} \mathrm{Hg}$ in still 13 (3/13/46 to 4/15/46). 


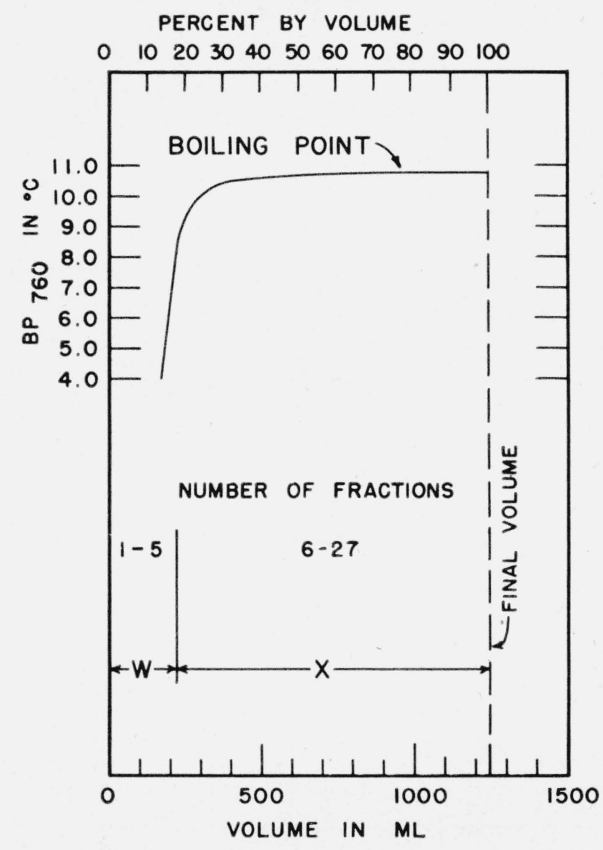

FiguRe 30.-Results of the first distillation of 1,2-butadiene. Regular distillation at atmospheric pressure in still 1 (6/21/45 to $7 / 24 / 45)$.

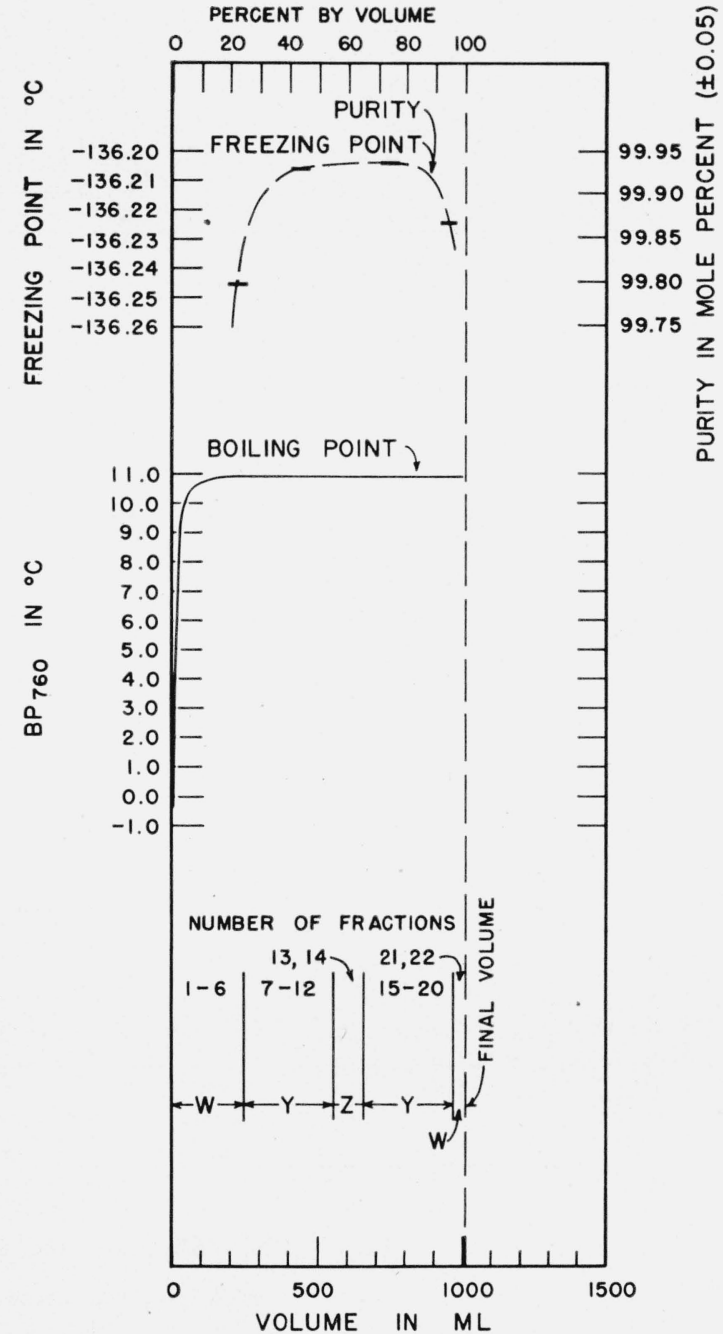

FIGURE 31.-Results of the second and final distillation of 1,2-butadiene.

Regular distillation at atmospheric pressure in still $1(2 / 28 / 46$ to $3 / 27 / 46)$. 


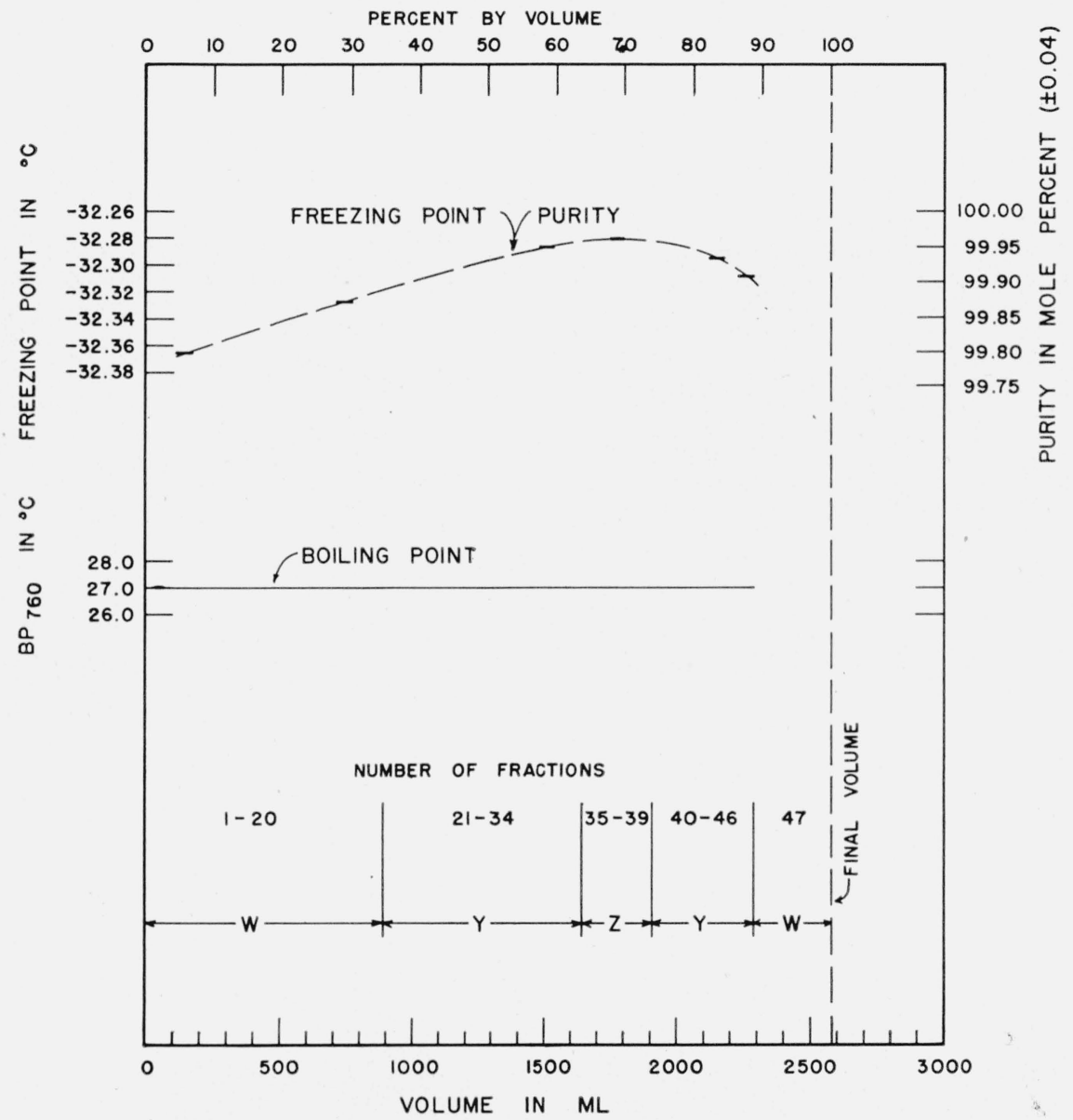

FIGURE 32.-Results of the first and only distillation of 2-butyne.

Regular distillation at atmospheric pressure in still 1 (11/8/45 to 1/7/46).

Washington, June 11, 1947. 